\title{
NBSIR 77-1437
}

\section{Solar Energy Systems - Standards for Rubber Seals}

Stiehler, R. D., Hockman, A., Embree, E. J.,

Masters, L. W., Existing standards inadequate for solar collector use, Solar Eng. 3, No. 8, 35-37 (Aug. 1978).

$$
2 / 0
$$

$\frac{\text { New }}{741}$

Prepared for

Department of Energy

Office of the Assistant Secretary

Conservation and Solar Applications

20 Massachusetts Avenue

Washington, DC 20545 



\section{SOLAR ENERGY SYSTEMS - STANDARDS FOR RUBBER SEALS}

Robert D. Stiehler Arthur Hockman Edward J. Embree Larry W. Masters

Structures and Materials Division Center for Building Technology National Engineering Laboratory National Bureau of Standards

Washington, DC 20234

March 1978

Final Report

Prepared for

Department of Energy

Office of the Assistant Secretary

Conservation and Solar Applications

20 Massachusetts Avenue

Washington, DC 20545



U.S. DEPARTMENT OF COMMERCE, Juanita M. Kreps, Secretary Dr. Sidney Harman, Under Secretary

Jordan J. Baruch, Assistant Secretary for Science and Technology

NATIONAL BUREAU OF STANDARDS, Emest Ambler, Director 


\section{ABSTRACT}

$\underline{\text { Page }}$

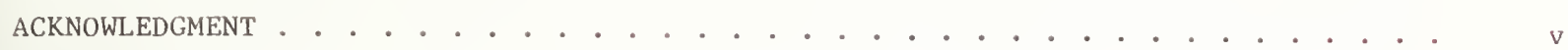

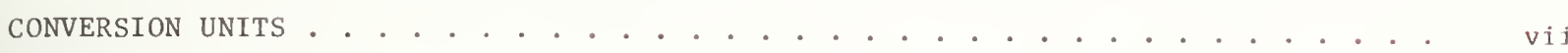

1. INTRODUCTION. . . . . . . . . . . . . . . . . . . . . . . . . . . . . 1

1.1 Background . . . . . . . . . . . . . . . . . . . . . . . . . . 1

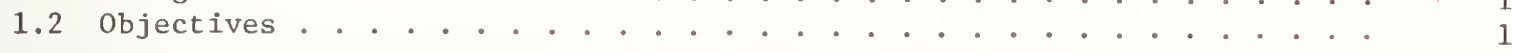

2. PROBLEM ASSESSMENT. . . . . . . . . . . . . . . . . . . . . . . . . . . . 2

2.1 Performance Requirements . . . . . . . . . . . . . . . . . . . . . . . . . 2

2.2 Key Properties . . . . . . . . . . . . . . . . . . . . . . . . . . . 2

2.3 Key Degradation Factors. . . . . . . . . . . . . . . . . . . . 2

3. LABORATORY STUDIES. . . . . . . . . . . . . . . . . . . . . . . . . . . . 2

3.1 Materials. . . . . . . . . . . . . . . . . . . . . . . . . . 2

3.2 ASTM Standard Rubber Tests Performed . . . . . . . . . . . . . . . . . 3

3.2.1 Samples 1 through 15. . . . . . . . . . . . . . . . . . . 3

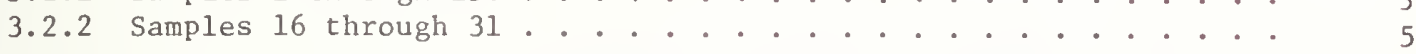

3.2.2.1 Loss in Mass (ASTM C792) . . . . . . . . . . . . 6

3.2.2.2 Hardness (ASTM C661) . . . . . . . . . . . . . . 6

3.2.2.3 Extension-Compression Cyclic Movement (ASTM C719). . . . 6

3.2.2.4 Accelerated Weathering (ASTM C793) . . . . . . . . 6

3.3 Studies to Evalúate the Effect of Outgassing . . . . . . . . . . . . 6

3.3 .1 Apparatus . . . . . . . . . . . . . . . . . . . . . . . . . . . . . . . . 7

3.3 .2 Procedure . . . . . . . . . . . . . . . . . . . . . . 7

4. RESULTS AND DISCUSSION •. . . . . . . . . . . . . . . . . . . . . . . . 7

4.1 ASTM Tests of Samples 1 through 15 . . . . . . . . . . . . . . . . . . 7

4.2 ASTM Tests of Samples 16 through 31... . . . . . . . . . . . . . . . . . . . 8

4.2.1 Loss in Mass . . . . . . . . . . . . . . . . . . . . . . . . . . . . . . . . 9

4.2 .2 Hardness. . . . . . . . . . . . . . . . . . . . . . . . . 9 9

4.2.3 Extension-Compression Cycles. . . . . . . . . . . . . . . . . . . . 9

4.2.4 Accelerated Weathering. . . . . . . . . . . . . . . . . 9

4.2.5 Conclusions from Samples 16 through 31............... . . . 10

4.3 Results of Outgassing Test Procedure . . . . . . . . . . . . . . . . 11

5. PROPOSED STANDARDS. . . . . . . . . . . . . . . . . . . . . . . . . . . 11

5.1 Standard Specification for Rubber Seals Used in Flat-Plate Solar Collectors . . . . . . . . . . . . . . . . . . . . . . . . . . . . . . 11

5.2 Standard Specification for Rubber Seals Contacting Liquids in Solar Energy Systems . . . . . . . . . . . . . . . . . . . . 13 
5.3 Standard Specification for Rubber Seals Used in Solar Collectors (other than Flat-Plate Collectors) . . . . . . . . . . . . . . .

5.4 Standard Test Method for Determining the Effect of outgassing on the Transmittance of Solar Collector Covers. . . . . . . . . . . . . . . .

5.5 Recommended Practice for Sealing Joints between Solar Collectors and Building Components with Rubber Seals. . . . . . . . . . . . . . .

6. BIBLIOGRAPHY . . . . . . . . . . . . . . . . . . . . . . . .

\section{APPENDICES}

Appendix A - Standard Specification for Rubber Seals Used in Flat Solar Collectors . . . . . . . . . . . . . . . . . . . A-1

Appendix B - Standard Specification for Rubber Seals Contacting Liquids in Solar Energy Systems. . . . . . . . . . . . . . . . . . . . A A

Appendix C - Standard Specification for Rubber Seals Used in Solar Collectors (other than Flat-Plate Collectors). . . . . . . . . . . . . A-14

Appendix D - Standard Test Method for Determining the Effect of Outgassing on the Transmittance of Solar Collector Covers . . . . . . . . . . A-22

Appendix E - Recommendations for Sealing Joints between Solar Collectors and Building Components with Rubber Seals . . . . . . . . . . . . A-27 


\section{ABSTRACT}

A study was performed to develop standards for rubber seals used in sular energy systems. Thirty-one preformed and liquid applied seals were evaluated In the laboratory using modified ASTM standard test methods to obtain data needed to evaluate those materlals and prepare new standards. Also, studies were performed to develop a test method for determining the effects of out gassing on the transmittance of solar collector covers.

The results of the laboratory tests are presented and standards for rubber seals in solar energy systems are proposed. 
The authors gratefully acknowledge the substantial contributions of Mr. George Bullman and Mr. Jack Lee of NBS performing the laboratory tests described in this report. The authors also thank Mr. Willard Roberts of NBS, who obtained the solar transmittance data, and the U.S. Department of Energy which supported this research.

In addition, the valuable review comments on draft standards provided by members of ASTM Committees DIl on Rubber and Rubber-like materials and C24 on Building Joint Sealants and Subcommittee E21.1D on Solar Heating and Cooling Applications are gratefully acknowledged. The authors also thank the many manufacturers of rubber materials and heat transport liquids who supplied samples for testing. 
In recognition of the position of the United States as a signatory to the General Conference on Weights and Measures, which gave official status to the international system of units in 1960, SI units of measurement have been used throughout this publication. To assist in conversion to common U.S. units of measurement, conversion factors have been provided in the table below. The reader interested in making further use of the coherent system of SI units is referred to:

NBS SP330, 1977 Edition, "The International System of Units ASTM E380-76 Standard for Practice (American National Standard 2210.1)

Table of Conversion Factors to Common U.S. Units

\begin{tabular}{lccc}
$\begin{array}{l}\text { Physical } \\
\text { Quantity }\end{array}$ & $\begin{array}{c}\text { To convert } \\
\text { from }\end{array}$ & to & Multiply by \\
\hline Length & meter & inch & 39.3701 \\
Area & $\mathrm{m}^{2}$ & in $^{2}$ & 1550.0031 \\
Temperature & Celsius & Fahrenheit & $\mathrm{t}_{\mathrm{F}}=\mathrm{t}_{\mathrm{C}}(1.8)+32$ \\
Mass & $\mathrm{kg}$ & $1 \mathrm{~b}$ & 2.2046 \\
Stress & $\mathrm{MPa}$ & $\mathrm{lbf} / \mathrm{in}^{2}$ & \\
\hline
\end{tabular}





\section{INTRODUCTION}

\subsection{Background}

Rubber seals are used extensively in solar energy systems to seal or weather-proof joints between adjoining materials or to separate dissimilar metallic materials. For example, rubber seals may be used in solar collectors to seal joints around cover plates and absorber plates as well as joints in the collector enclosure. They may be used as hydraulic seals within heat transport or storage subsystems to prevent leakage of fluids. In addition, they may be used to seal joints between solar system components and the building the system serves.

Numerous standard test methods have been developed for rubber seals for use in building constructions. However, the performance requirements established for seals used in building constructions are not entirely adequate for solar energy systems and subsystems. This is particularly true for seals used in solar collectors, where they may be exposed to high temperature, and for hydraulic seals which may be degraded by transport or storage liquids with which they contact. For example, existing standard tests seldom specify temperatures exceeding $70^{\circ} \mathrm{C}$. This temperature limit is based upon the maximum service temperature encountered by seals in bulldings. It has been established that temperatures of materials in solar energy systems and subsystems will exceed those observed in conventional building applications. The maximum service temperature of interior cover plates used in flat plate solar collectors is estimated to be about $150^{\circ} \mathrm{C}$ while that for absorptive surfaces is estimated to be $250^{\circ} \mathrm{C}$ or greater depending on the design of the collector and the materials used $[1]^{1}$. In addition, hydraulic seals may be exposed to heat transport and storage liquid temperatures that are not covered by existing standards.

Skoda and Masters [2] reported that rubber seals have failed or exhibited problems in numerous operational solar energy systems. Problems include loss of elasticity, bond failure to the substrates and thermal decomposition (outgassing) leading to the formation of deposits on the underside of collector cover plates. These problems with seals can lead to reduced thermal performance of collectors and to accelerated degradation of other system or building components.

There is clearly a need for the development of standard for rubber seals for solar energy systems and subsystems to ensure that they will perform adequately when initially installed and when subjected to in-service conditions for extended periods of time.

\subsection{Objectives}

The study of rubber seals for use in solar energy systems was directed toward the following objectives:

II Numbers in brackets refer to the references in the Bibliography at the end of this report. 
1. To identify performance requirements for rubber seals used in solar energy systems.

2. To identify and assess existing test methods for rubber seals and modify the methods or develop new methods as needed.

3. To evaluate commercially available rubber materials in the laboratory and obtain data needed to recommend specific test methods.

4. To prepare draft standards for rubber seals for consideration by ASTM as consensus standards.

\section{PROBLEM ASSESSMENT}

\subsection{Performance Requirements}

The primary function of rubber seals used in solar energy systems is to seal or weatherproof the joints between materials or components. Rubber seals include both preformed gasketing and liquid applied sealants.

In order to perform their primary function, both preformed and liquid applied seals must possess and maintain sufficient elasticity to permit movement within a joint. In addition, liquid applied seals must develop and maintain adhesion to the substrates. In general, rubber seals should be capable of performing their intended functions when initially installed and after long term exposure to service conditions. In particular, they should be resistant to deterioration resulting from exposure to elevated and depressed temperature, temperature cycles, solar radiation, oxygen, ozone and airborne pollutants. They should also be compatible with adjoining materials. This is particularly important for preformed hydraulic seals which are in contact with heat transfer or storage liquids.

\subsection{Key Properties}

Key properties of rubber seals include ultimate elongation, compression set, hardness, tensile strength, low temperature flexibility, volatile content, condensible volatiles and adhesion (for liquid applied seals). Table 1 lists ASTM test methods for these properties.

\subsection{Key Degradation Factors}

Degradation factors that could affect the properties of rubber seals and thereby reduce their ability to perform are elevated and depressed temperature, ozone, ultraviolet radiation, stresses imposed by cyclic joint movement and contact with liquids. Table 2 lists ASTM test methods for exposure of rubber seals to these degradation factors.

\section{LABORATORY STUDIES}

\subsection{Materials}

The rubber seals selected for laboratory testing included the following types: 


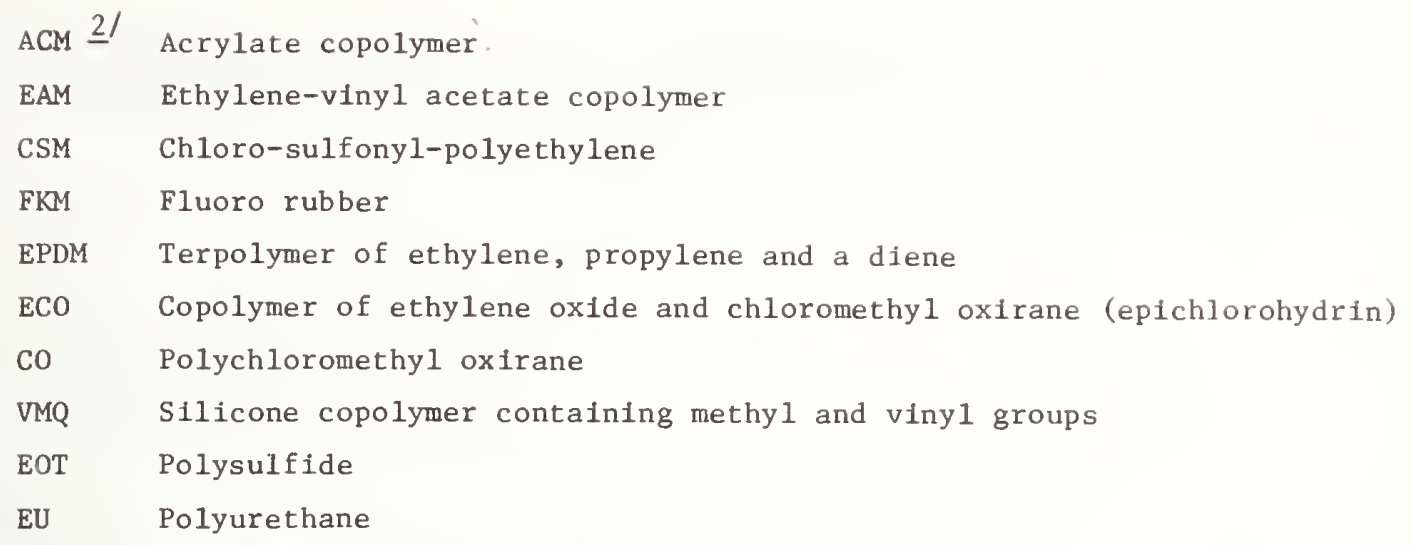

Table 3 is a listing of the rubber samples tested and the form in which they were received for testing from manufacturers, 1.e., vulcanized sheet, liquid applied seals, etc.

\subsection{ASTM Standard Rubber Tests Performed}

\subsubsection{Samples 1 through 15}

Samples 1 through 15 were tested as vulcanlzed sheets. Samples 13 and 15, which were supplied as liquid applied seals, were prepared as sheets before testing. The following tests were made:

$\begin{array}{ll}\text { ASTM D395 } & \text { Test for Rubber Property-Compression Set } \\ \text { ASTM D412 } & \text { Test for Rubber Properties 1n Tension } \\ \text { ASTM D865 } & \text { Test for Rubber Deterioration by Heating in a Test Tube } \\ \text { ASTM D1149 } & \text { Test for Rubber Deterioration-Surface Ozone Cracking in a Chamber } \\ & \text { (Flat Specimen) } \\ \text { ASTM D1229 } & \text { Test for Rubber Property-Compression Set at Low Temperature } \\ \text { ASTM D1415 } & \text { Test for Rubber Property-International Hardness } \\ \text { ASTM D2137 } & \text { Test for Rubber Property-Brittleness Point of Flexible Polymers } \\ & \text { and Coated Fabrics }\end{array}$

The above tests were selected for the following reasons:

D395 is useful to assess the proper state of vulcanization and the ability to retain a seal after exposure to high temperatures.

$\underline{\mathrm{D}} 12$ is generally used to assess the quality of the rubber and, in conjunction with an aging test, to determine the ability of a rubber to be serviceable for long periods.

D865 is a commonly used test for accelerated aging and is convenient for determining total volatiles at test temperatures and volatiles condensible at room temperature.

2/ ASTM D1418-76 rubber designations. 
D1149 is an important test used to assess the ability of rubber to withstand cracking by ozone, the component in the atmosphere which causes the greatest deterioration of rubber.

D1229 is used to determine the tendency of a rubber to crystallize at low temperature and lose its ability to seal.

D1415 is used to measure hardness (a measure of Young's modulus) that is important for design purposes, and is useful in conjunction with an accelerated aging test to assess deterioration of rubber.

D2240 gives equivalent results but requires specimens at least 6 mm thick, which may not be possible to obtain from some seals.

D2137 is used to assure rubbery properties at the low temperatures occurring during winter in cold climates. This test is not required for seals used in warm climates (Winter temperatures above $-10^{\circ} \mathrm{C}$ )

In addition to the above tests, the total volatiles at $150^{\circ} \mathrm{C}$ and the volatiles condensible at $23^{\circ} \mathrm{C}$ were determined by a modification of the procedure in ASTM D865. The difference in mass of the specimens before and after heating at $150^{\circ} \mathrm{C}$ was used to determine total volatiles. The material collecting on the glass tubes used in ASTM D865 was weighed to determine the amount of condensible volatiles.

The total and condensible volatiles were measured to determine the amount of material that could possibly cause fogging of the cover plates and absorption of scattering of solar energy. Such volatiles may reduce the cover plate transmittance and thereby affect the efficiency of a solar collector.

Available information [1,3] indicated that the highest temperature for seals around cover plates in flat-plate solar collectors would normally be less than $150^{\circ} \mathrm{C}$. Under normal operating conditions, temperatures would be much lower than under static non-operating conditions. Therefore, a test temperature of $150^{\circ} \mathrm{C}$ was used in these studies for assessing high temperature performance. If a seal were in contact with an absorber plate, the test temperature would depend on the maximum service temperature for a particular design or type. Hence, tests were not made on materials for this application. Since early studies showed that liquid applied seals (samples 13 and 15) would be sultable only for external use where stresses on the seal are very small and temperatures are lower, they were tested at a test temperature of $125^{\circ} \mathrm{C}$. To assess performance at low temperature, a test temperature of $-10^{\circ} \mathrm{C}$ was selected to detect crystallization of the rubber by means of compression set. A test temperature of $-40^{\circ} \mathrm{C}$ was selected to assess brittleness of seals in cold winter climates because this temperature is estimated to be the lowest likely in the continental United States. 
In addition to the above methods, liquid immersion tests were performed to obtain data regarding the performance of rubbers for use in direct contact with various heat transport or storage liquids.

Test specimens of samples 1 through 12 were immersed in various liquids for a period of 7 days using a modification of ASTM D471, Test for Rubber Property - Effect of Liquids. The liquids used were as follows: $\underline{3}$ /

1. Ethylene glycol-water $(1: 1)$

2. Propylene glycol-water $(1: 1)$

3. Polyalkylene glycol ether (U CON 500)

4. Modified ester (Therminol 44)

5. Polyaromatic (Therminol 60)

6. Modified terphenyl (Therminol 66)

7. Silicone A (Dow Q2-1132)

8. Silicone B (Dow X2-1133)

9. Silicone C (GE SF 96-100)

10. Alkyated aromatic (Dowtherm J).

The test temperature for liquids 1 and 2 was $100^{\circ} \mathrm{C}$ to avoid boiling, while that for other liquids was $150^{\circ} \mathrm{C}$. The changes in mass and hardness as a result of the immersion were determined. These temperatures were selected to cover most applications. Seals for solar energy systems operating above $150^{\circ} \mathrm{C}$ were beyond the scope of this study.

3.2.2 Samples 16 through 31

Four test methods related to performance of sealants and described in ASTM Book of Standards, Part 18 (1976) were used, with some modifications, in evaluating samples 16 through 31 of table 3 . The methods were:

ASTM C792, Test for Effects of Heat Aging on Weight Loss Cracking and Chalking of Elastomeric Sealants

ASTM C661, Test for Indentation Hardness of Elastomeric-Type Sealants by Means of Durometer

ASTM C719, Test for Adhesion and Cohesion of Elastomeric Joint Sealants Under Cyclic Movement

ASTM C793, Test for Effects of Accelerated Weathering on Elastomeric Joint Sealants

3/ Trade names are included where necessary to describe more clearly the liquids used in the study. Reference to these liquids does not imply approval of the National Bureau of Standards for use of the liquids in solar energy systems. 


\subsubsection{Loss in Mass (ASTM C792)}

After vulcanization for 7 days at room temperature duplicate specimens were oven aged at temperatures of $82,100,121$ and $125^{\circ} \mathrm{C}$ for 7 days. After the aging, losses in mass were determined and examinations were made for cracks.

\subsubsection{Hardness (ASTM C661)}

This test was made on the same specimens used for the loss in mass determination. Instantaneous hardness values were obtained after exposures of the specimens at the respective temperatures $\left(82,100,121,125^{\circ} \mathrm{C}\right)$. This test is essentially the same as ASTM D2240, and includes the preparation of the specimen.

\subsubsection{Extension-Compression Cyclic Movement (ASTM C719)}

Four sets of sealant specimens were prepared from each sealant sample for the extensioncompression test. A test specimen consisted of a joint, $50 \times 12 \times 12 \mathrm{~mm}$, filled with the sealant sample between two pieces of standard aluminum. Each set was fabricated in triplicate. After specimen preparation, the following steps were used in the evaluation procedure:

1. Cure for three weeks at room temperature.

2. Immerse in distilled water at room temperature for 7 days.

3. Compress 12.5 percent and oven age at temperatures of 82,100 and $121^{\circ} \mathrm{C}$ for 7 days (triplicate specimens at each temperature).

4. Perform 10 cycles with each cycle consisting of a) oven aging at each of the above temperatures while spectmens are compressed 12.5 percent and b) cooling at $-26^{\circ} \mathrm{C}$ while specimens are compressed 12.5 percent.

During and after the cycling procedure, the specimens were examined for adhesive, cohesive and deformation failures.

In addition to the above tests, a number of the samples were tested after bonding to glass substrates (rather than aluminum). These specimens were tested using steps 1 through 4 with the following exception: the temperature during oven aging in steps 3 and 4 was $125^{\circ} \mathrm{C}$.

\subsubsection{Accelerated Weathering (ASTM C793)}

Eight test specimens, each consisting of $50 \times 38 \times 30 \mathrm{~mm}$ sealant pats on aluminum plates were prepared for each of the 16 samples. After curing for three days at room temperature, two specimens of each sample were exposed to the respective elevated temperatures in ovens set at $82,100,121,125^{\circ} \mathrm{C}$ for seven days. Following the oven exposure, the specimens were exposed to UV radiation in a carbon arc accelerated weathering machine for 1000 hours. At the end of the UV exposure, the specimens were placed in a freezer at $-26^{\circ} \mathrm{C}$ for 24 hours and then bent over a $12.7 \mathrm{~mm}$ mandrel at $-26^{\circ} \mathrm{C}$. Examination was made for the presence of cracks.

\subsection{Studies to Evaluate the Effect of Outgassing}

One problem frequently reported in operational solar systems is called outgassing. Figure 1 shows the fogging of collector covers by outgassing. It results from the thermal 
degradation of polymers with the subsequent depositon of degradation products on the underside of collector covers. The volatile condensible measurements, using a modification of ASTM D865, described in 3.2.1, relate to outgassing. But this method provides no means of determining the effect of the volatile condensibles on cover plate transmittance. A study was performed to determine the effect of the volatile condensibles and to develop a new test method for evaluating outgassing.

\subsubsection{Apparatus}

Figure 2 is a photograph of the apparatus used. The key components are a hot plate, a specimen holder, a Teflon gasket, a glass plate upon which volatiles are condensed and a filtered air stream to cool the glass plate. The gasket and glass plate are held in place with two spring clips.

\subsubsection{Procedure}

Specimens of samples that had been evaluated for volatile condensibles by the modified ASTM method D865 were heated to $150^{\circ} \mathrm{C}$ for periods of either 3 or 6 hours. The transmittance of the glass plate was measured at 50 nanometers $(\mathrm{nm})$ increments in the range from 300 to 2100 nanometers (nm) before and after the test. Also, the masses of the glass plate and the rubber test specimens were obtained before and after the test.

Test temperature was measured using a copper constantan thermocouple attached to the hot plate. The hot plate was adjusted to reach a temperature of $150 \pm 2^{\circ} \mathrm{C}$ before placing the rubber test specimen in the chamber, installing the teflon gasket and placing the glass plate on the apparatus. An air stream was passed over the exterior surface of the glass plate during the test to cool the glass and allow the condensate to form on its underside.

\section{RESULTS AND DISCUSSION}

\subsection{ASTM Tests of Samples 1 through 15}

Table 4 sumarizes the results obtained with samples 1 through 15. This table gives the code number and type of rubber and median values for three specimens in the case of hardness, tensile strength, ultimate elongation and volatiles, and for two specimens in the case of compression set, low temperature flexibility, and ozone resistance.

Five materials (samples 5, 8, 9, 10 and 14) which had a high compression set were retested for compression set after post-vulcanization. The post-vulcanization procedure consisted of placing uncompressed specimens in an oven at $150^{\circ} \mathrm{C}$ for 70 and 166 hours. The specimens were then compressed, as in ASTM D395, and exposed for 70 hours at $150^{\circ} \mathrm{C}$ prior to measuring compression set. The compression set was reduced in most instances after postvulcanization, as can be seen in table 5. These results indicate that these rubbers were not properly formulated to give optimum properties for solar collectors. In particular, the data in tables 4 and 5 for EPDM samples 5, 6, 7 and 8 indicate that only Sample 7 (of 
the EPDM samples) was properly formulated for solar applications.

A study of the results in tables 4 and 5 indicates that several kinds of rubber, when properly vulcanized, are suitable for use as seals in flat-plate solar collectors. These rubbers are EAM, EPDM (when properly formulated and vulcanized), and VMQ, which are suitable for use in all climates, and ACM and FKM, which are suitable for use in warm climates only. Rubber types CSM, ECO and CO have higher compression sets than desirable for preformed gaskets. It may be possible to develop formulations for these rubbers which would be satisfactory. The compression set values in table 5 were used in drawing conclusions on samples 5, 8, 9, 10 and 14 . The 100 percent compression sets of samples 13 and 15 indicated that sealing compounds should be applied only where there is no mechanical stress

The polysulfide rubber (EOT) tested was not suitable for use in solar collectors since it melted at $150^{\circ} \mathrm{C}$ and in subsequent tests at $125^{\circ} \mathrm{C}$. A high temperature type of polysulfide would be required. A test temperature of $125^{\circ} \mathrm{C}$ was considered the lower limit for seals exposed to summer sunshine. For vertical solar collectors used for winter heating, conventional building sealants should be satisfactory.

Table 6 summarizes the results of the liquid immersion tests. In the aqueous liquids 1 and 2, all of the rubbers performed satisfactorily except the acrylate rubber, ACM, which softened appreciably more than the others (hardness decrease of 12 and 16 IRHD in the two liquids.

The fluoro rubber, FKM, is the only one that performed satisfactorily in all liquids. The epichlorohydrin rubber, $\mathrm{CO}$, tended to corrode the steel wire support and in one case completely corroded the wire during the tests at $150^{\circ} \mathrm{C}$. In the eight organic liquids at $150^{\circ} \mathrm{C}$, the following rubbers performed satisfactorily:

\begin{tabular}{ll} 
Liquid & \multicolumn{2}{c}{ Rubbers } \\
3 & CSM, FKM, EPDM ${ }^{*}, V M Q$ \\
4 & FKM \\
5 & FKM, VMQ \\
6 & FKM, VMQ \\
$7,8,9$ & ACM, EAM, FKM, EPDM * \\
10 & FKM \\
& \\
* Proper1y Vulcanized. &
\end{tabular}

These results indicate that rubber seals in contact with heat transfer liquids should be evaluated in the specific liquid to be used.

\subsection{ASTM Tests of Samples 16 through 31}

Table 7 summarizes the results obtained on samples 16 through 31. 


\subsubsection{Loss in Mass}

The data in table 7 show that the mass losses for silicone sealants ranged from 3.2 to 8.1 percent while mass losses for polysulfides range from 4.0 to 13.6 percent. The two polyurethane sealants, Samples 30 and 31, had mass losses ranging from 11.8 to 21.0 percent.

\subsubsection{Hardness}

The hardness data in table 7 show that silicone sealants had hardness values of from 27 to 44 after exposure at the four temperatures. The values for silicones were relatively independent of the test temperature. The hardness range for polysulfides was from 0 to 65 units. Two polysulfides, Samples 25 and 26, became harder with increasing temperature while others, Samples 22 and 27, became softer. The hardness values of the two polyurethane samples ranged from 45 to 69 .

\subsubsection{Extension-Compression Cycles}

Bond loss in the extension-compression test was rated as being greater than or less than 25 percent. The value represents bond to the substrate and cohesive bond within the sealant.

The test results in table 7 show that four of the six silicone samples with aluminum substrate had less than $25 \%$ bond loss after exposure to the four temperatures. of the five silicone samples tested with glass at $125^{\circ} \mathrm{C}$, two had less than $25 \%$ bond 1 oss.

Seven of the eight polysulfides that were tested after exposure to 82,100 and $121^{\circ} \mathrm{C}$ test conditions exhibited more than $25 \%$ bond loss in eleven instances and 1 ess than $25 \%$ bond loss in ten instances.

One polyurethane sample (Number 30), had more than.25\% bond loss at the four test temperatures and the other polyurethane sample (Number 31) had less than 25\% bond 1oss at al1 test temperatures.

\subsubsection{Accelerated Weathering}

The accelerated weathering results in table 7 indicate that none of the silicone sealants developed cracks after 1000 hours UV exposure nor did any cracks develop after the $180^{\circ}$ bend test at $-26^{\circ} \mathrm{C}$.

Seven of the eight polysulfide sealants tested developed no cracks after exposure at each of four temperatures followed by 1000 hours in the weatherometer. The specimens of 
sample 23 that were exposed to 100, 121 and $125^{\circ} \mathrm{C}$ showed cracks after UV treatment. Samples 23, 24, 26, 27 and 29 developed cracks after the bend test following exposure to one or more of the temperature treatments.

of the two polyurethane samples tested, one (Sample 31) developed cracks after UV exposure. The cracks deepened after the bend test at $-26^{\circ} \mathrm{C}$. The other, sample 30 , did not crack after UV exposure but developed cracks after one bend test.

\subsubsection{Conclusions from Samples 16 through 31}

The test results indicate that silicone sealants might be the best choice for sealing joints around solar collectors where the sealant temperatures may reach $125^{\circ} \mathrm{C}$. Polysulfide and polyurethane sealants tend to be adversely affected by these elevated temperatures. However, the test results also indicate that bonding properties of some of the silicone sealants to certain substrates are unsatisfactory.

It is probable that in addition to silicones, polysulfide and perhaps certain polyurethane sealants may be suitable for the installation of solar collector units where substrate and sealant temperatures do not exceed $80^{\circ} \mathrm{C}$. These polymers have been used sucessfully in building joints for the past several years.

\subsection{Results of Outgassing Test Procedure}

Table 8 summarizes the results obtained with the outgassing test apparatus and procedure described in 3.3. The table also compares the results of the outgassing test with the results obtained with modified ASTM D865 (table 4).

Since both tests were run at $150^{\circ} \mathrm{C}$, the percent volatiles would be expected to be comparable in the two tests. For example, the three and six hour exposures using the outgassing procedure would be expected to yield lower volatile contents than the 70 and 166 hour exposures using modified ASTM D865. Only sample 5 results are approximately comparable to the expected results. The apparent discrepancies cannot be explained at this point.

The percent condensibles obtained by the two tests are reasonably comparable except for samples 7 and 8 . The condensibles obtained for sample 7 by modified ASTM D865 were 0.04 and 0.05 percent at 70 and 166 hours, respectively, while the outgassing test yielded results of 0.15 and 0.25 percent at 3 and 6 hours, respectively. For sample 8 , the outgassing test yielded lower condensibles than the modified ASTM D865. The change in transmittance does not appear to be directly related to the gross weight of condensibles collected on the glass. It is probable that the chemical composition of the condensibles is more important than the amount of condensibles in evaluating their effect on transmittance. 
These preliminary results of studies to develop a new outgassing test are inconclusive and additional work is needed. We believe, however, that the test procedure is sound since it closely simulated collector outgassing. A test procedure, based on the studies performed, is proposed in Appendix D to this report. Additional work will be done to obtain answers to the questions raised by this preliminary work. Also additional materials, such as absorptive coatings and insulation, w111 be studied with the outgassing apparatus and attempts will be made to correlate the test results with changes observed in solar collectors in the field.

\section{PROPOSED STANDARDS}

Based upon the results of the laboratory tests described in Chapters 3 and 4, standards have been prepared for rubber seals in solar systems. The proposed standards are included in the following Appendices to this report:

Appendix A - Standard Specification for Rubber Seals Used in Flat-Solar Collectors Appendix B - Standard Specification for Rubber Seals Contacting Liquids in Solar Energy Systems

Appendix C - Standard Specification for Rubber Seals Used in Solar Collectors (other than Flat-P1ate Collectors)

Appendix D - Standard Test Method for Determining the Effect of Outgassing on the Transmittance of Solar Collector Covers

Appendix E - Recommendations for Sealing Joints between Solar Collectors and Building Components with Rubber Seals

\subsection{Standard Specification for Rubber Seals Used in Flat-Plate Solar Collectors}

Appendix A is a proposed specification for rubber seals used in flat-plate solar collectors except vertically mounted passive collectors. The document is based upon the laboratory test results of the samples in table 3 (except the liquid immersion tests) and is being considered for acceptance as a consensus standard by ASTM Committee D11 on Rubbers, Subcommittee $\mathrm{D} 11.36$ on Seals.

The proposed standard defines two types of seals; one for use in all climates (Type C) and the other for use only in regions where minimum temperatures are above $-10^{\circ} \mathrm{C}$ (Type $\mathrm{W}$ ) The requirements for the two types are the same with the exception of resistance to low temperature.

The proposed standard establishes six grades of preformed rubber seals and three grades of sealing compounds. The grade to be used depends on the design of the seal or solar collector, particularly on the stresses likely to be placed on the seal during the life of the solar collector. 
A requirement is included to minimize the possibility of deterioration by ultraviolet 1ight. Physical requirements include (1) minimum elongation values for each grade, (2) compression set after heating at $150^{\circ} \mathrm{C}$ for 70 hours to assure that the seal will be effective in service for extended periods of time, (3) compression set after exposure at $-10^{\circ} \mathrm{C}$ for 166 hours to assure that crystallization of the rubber polymer will not cause an air leak, (4) resistance to heating and ozone to assure that deterioration of the seal will be slow and not adversely affect the performance of the collector during its expected 1ife, (5) resistance to low temperatures for seals likely to be at low temperatures (below $-10^{\circ} \mathrm{C}$ ) during winters and (6) total and condensible volatile matter.

The requirements for compression set are not applicable to sealing compounds and the test for resistance to heating of sealing compounds is conducted at $125^{\circ} \mathrm{C}$ instead of $150^{\circ} \mathrm{C}$ or more used for preformed rubber seals. An adhesion requirement is included for sealing compounds to assure maintenance of the seal during repeated thermal expansion and contractions of the members of the solar collector. ASTM C792 is not used for loss in mass since it is not easy to modify for determining condensible volatile matter.

The design of the seal is not specified except for a limitation on the amount of thermal expansion and contraction which could cause failure of the seal or a loss in its sealing ability. Commercial tolerances are specified for design dimensions of preformed seals. The proposed standard also includes requirements on workmanship, marking, and packaging, and gives instructions on procedures for sampling, inspection and testing.

\subsection{Standard Specification for a Rubber Seals Contacting Liquids in Solar Energy Systems}

Appendix B is a proposed specification for rubber seals for use in direct contact with heat transport or storage liquids. The document is based upon the laboratory test results of samples 1 through 15, including liquid immersion, as described in Chapters 3 and 4 . The standard is being considered for acceptance as a consensus standard by ASTM Committee D11 on Rubbers, Subcommittee D11.36 on Seals.

The proposed standard defines two types of seals; one for use in all climates (Type C) and the other for use only in regions where minimum temperatures are above $-10^{\circ} \mathrm{C}$ (Type $\mathrm{W}$ ) The requirements for the two types are the same with the exception of resistance to low temperature.

The proposed standard establishes six grades of preformed rubber seals and two classes: A, for use with aqueous liquids, and $N$, for use with non-aqueous liquids. The grade to be used depends on the design of the seal and solar collector, particularly on the stresses likely to be placed on the seal during the life of the solar collector.

Physical requirements include (1) minimum elongation values for each grade, (2) compression set after exposure to elevated temperature for 70 hours to assure that the seal will be effective in service, (3) compression set after exposure at $-10^{\circ} \mathrm{C}$ for 166 hours to 
assure that crystallization of the 'rubber polymer will not cause leakage, (4) resistance to heating and ozone to assure that deterioration of the seal will be slow and not adversely affect the performance of the system during its expected 11fe, (5) resistance to low temperatures for seals 11kely to be at low temperatures (below $-10^{\circ} \mathrm{C}$ ) during winters and (6) resistance to liquid immersion.

The design of the seal is not specified except for a limitation on the amount of thermal expansion and contraction which could cause fallure of the seal or a loss in its sealing ability. Commercial tolerances are specifled for design dimensions of preformed seals. The proposed standard also includes requirements on workmanship, marking and packaging, and gives instructions on procedures for sampling, inspection and testing.

5.3 Standard Specification for Rubber Seals Used In Solar Collectors (other than FlatPlate Collectors)

Appendix C is a proposed specification for rubber seals used in solar collectors other than flat-plate collectors. This standard is intended for use with vertically mounted passive systems as well as curved concentrating collectors. The document is identical to the standard in Appendix A, except that elevated test temperatures are related to the maximum in-service temperatures. Specifying the test temperature in this manner is necessary because of the broad range of temperatures which can be reached with various collector designs. The maximum temperature will normally be attalned under stagnation conditions when the collector is receiving the maximum radiation flux to which 1 t w111 be exposed.

5.4 Standard Test Method for Determining the Effect of Outgassing on the Transmittance of Solar Collector Covers

Appendix D is a proposed test method for determining the effect of outgassing on the transmittance of solar collector covers. The document is based upon the apparatus and procedure described in 3.3 and upon the test results described in 4.3.

\subsection{Recommendations for Sealing Joints between Solar Collectors and Building Components with Rubber Seals}

Appendix E includes recommendations for sealing the joints between solar collectors and building components with rubber seals. The document applies to 1) joints between collectors integral with building components and those building components and 2) joints between collector standoffs and the roof or other building components.

\section{BIBLIOGRAPHY}

[1] Interim Performance Criteria for Solar Heating and Cooling Systems in Commercial Buildings, NBSIR 76-1187, National Bureau of Standards Report (November 1976).

[2] Skoda, Leopold F. and Masters, Larry W., Solar Energy Systems - Survey of Materials Performance, NBSIR 77-1314, National Bureau of Stnadards Report (October 1977 ).

[3] Unpublished NBS temperature data obtained on the materlals of two types of collectors under stagnation conditions (1977). 
Table 1. ASTM Test Method for Measuring Key Properties of Rubber Seals

\section{Property}

Ultimate Elongation

Compression Set

Hardness

Tensile Strength

Low Temperature Flexibility

Volatile Content and

Condensible Volatiles

Adhesion

\section{ASTM Designation}

D412

D 395 (Method B), D1229

D1415, D2240

D412

$\mathrm{C} 711, \mathrm{C} 734, \mathrm{C} 765, \mathrm{D} 2137$

D865

C719

Table 2. ASTM Test Methods for Exposure of Rubber Seals to Key Degradation Factors

\section{Degradation}

Elevated Temperature

Depressed Temperature

Ozone

Ultraviolet Radiation

Stresses via Joint Movement

Liquid Immersion

\section{ASTM Designation}

C771, C792, D865

D1229， D 2137

D1149

C732, C793

C719

D471 
Table 3. Rubbers Used in Laboratory Testing

\begin{tabular}{|c|c|c|c|}
\hline $\begin{array}{l}\text { Sample } \\
\text { Number }\end{array}$ & $\begin{array}{c}\text { ASTM } \\
\text { Designation }^{1}\end{array}$ & Type & $\begin{array}{l}\text { Form In Which } \\
\text { Received }\end{array}$ \\
\hline 1 & $\mathrm{ACM}$ & Acrylate Copolymer & Vulcanized Sheet \\
\hline 2 & EAM & Ethylene-Vinyl Acetate Copolymer & Vulcanized Sheet \\
\hline 3 & $\operatorname{CSM}$ & Chloro-Sulfonyl-Polyethylene & Vulcanized Sheet \\
\hline 4 & FKM & Fluoro Rubber & Vulcanized Sheet \\
\hline 5 & EPDM & $\begin{array}{l}\text { Terpolymer of Ethylene, Propylene } \\
\text { and a Diene }\end{array}$ & Vulcanized Sheet \\
\hline 6 & EPDM & $\begin{array}{l}\text { Terpolymer of Ethylene, Propylene } \\
\text { and a Diene }\end{array}$ & Vulcanized Sheet \\
\hline 7 & EPDM & $\begin{array}{l}\text { Terpolymer of Ethylene, Propylene } \\
\text { and a Diene }\end{array}$ & Vulcanized Sheet \\
\hline 8 & EPDM & $\begin{array}{l}\text { Terpolymer of Ethylene, Propylene } \\
\text { and a Dlene }\end{array}$ & Vulcanized Sheet \\
\hline 9 & ECO & $\begin{array}{l}\text { Copolymer of Ethylene Oxide and } \\
\text { Chloromethyl Oxirane } \\
\text { (Epichlorohydrin) }\end{array}$ & Vulcanized Sheet \\
\hline 10 & $\mathrm{CO}$ & Polychloromethy1 Oxirane & Vulcanized Sheet \\
\hline 11 & VMQ & Silicone Copolymer & Vulcanized Sheet \\
\hline 12 & VMQ & S11icone Copolymer & Vulcanized Sheet \\
\hline 13 & VMQ & Silicone Copolymer & Liquid Applied Seal \\
\hline 14 & VMQ & Silicone Copolymer & Cellular Rubber \\
\hline 15 & EOT & Polysulfide & LIquid Applied Seal \\
\hline 16 & VMQ & Silicone & Liquid Applled Seal \\
\hline 17 & VMQ & Silicone & Liquid Applied Seal \\
\hline 18 & VMQ & Silicone & Liquid Applied Seal \\
\hline 19 & $\mathrm{VMQ}$ & Silicone & Liquid Applied Seal \\
\hline 20 & VMQ & Silicone & Liquid Applied Seal \\
\hline 21 & VMQ & Silicone & Liquid Applied Seal \\
\hline 22 & EOT & Polysulfide & Liquid Applied Seal \\
\hline 23 & EOT & Polysulfide & Liquid Applied Seal \\
\hline 24 & EOT & Polysulfide & Liquid Applied Seal \\
\hline 25 & EOT & Polysulfide & Liquid Applied Seal \\
\hline 26 & EOT & Polysulfide & Liquid Applied Seal \\
\hline 27 & EOT & Polysulfide & Liquid Applied Seal \\
\hline 28 & EOT & Polysulfide & Liquid Applied Seal \\
\hline 29 & EOT & Polysulfide & Liquid Applied Seal \\
\hline 30 & $\mathrm{EU}$ & Polyurethane & Liquid Applied Seal \\
\hline 31 & $\mathrm{EU}$ & Polyurethane & Liquid Applied Seal \\
\hline
\end{tabular}

1 ASTM D1418-76 
Table 5. Repeat of Compression Set Measurements 1/

after Post Vulcanization

\begin{tabular}{ccccc}
\hline \multirow{2}{*}{$\begin{array}{c}\text { Sample } \\
\text { Number }\end{array}$} & $\begin{array}{c}\text { ASTM } \\
\text { Designation }\end{array}$ & \multicolumn{2}{c}{ Post Cure in Air of Uncompressed Specimens } \\
\cline { 3 - 5 } 5 & None & 100 & $70 \mathrm{~h}$ at $150^{\circ} \mathrm{C}$ & $166 \mathrm{~h}$ at $150^{\circ} \mathrm{C}$ \\
\hline 8 & EPDM & 82 & 53 & 38 \\
9 & EPDM & 54 & 71 & 60 \\
10 & ECO & 54 & 51 & 48 \\
14 & CO & 49 & 82 & 32 \\
\hline
\end{tabular}

1/ Percent set after compression for 70 hours at $150^{\circ} \mathrm{C}$. 


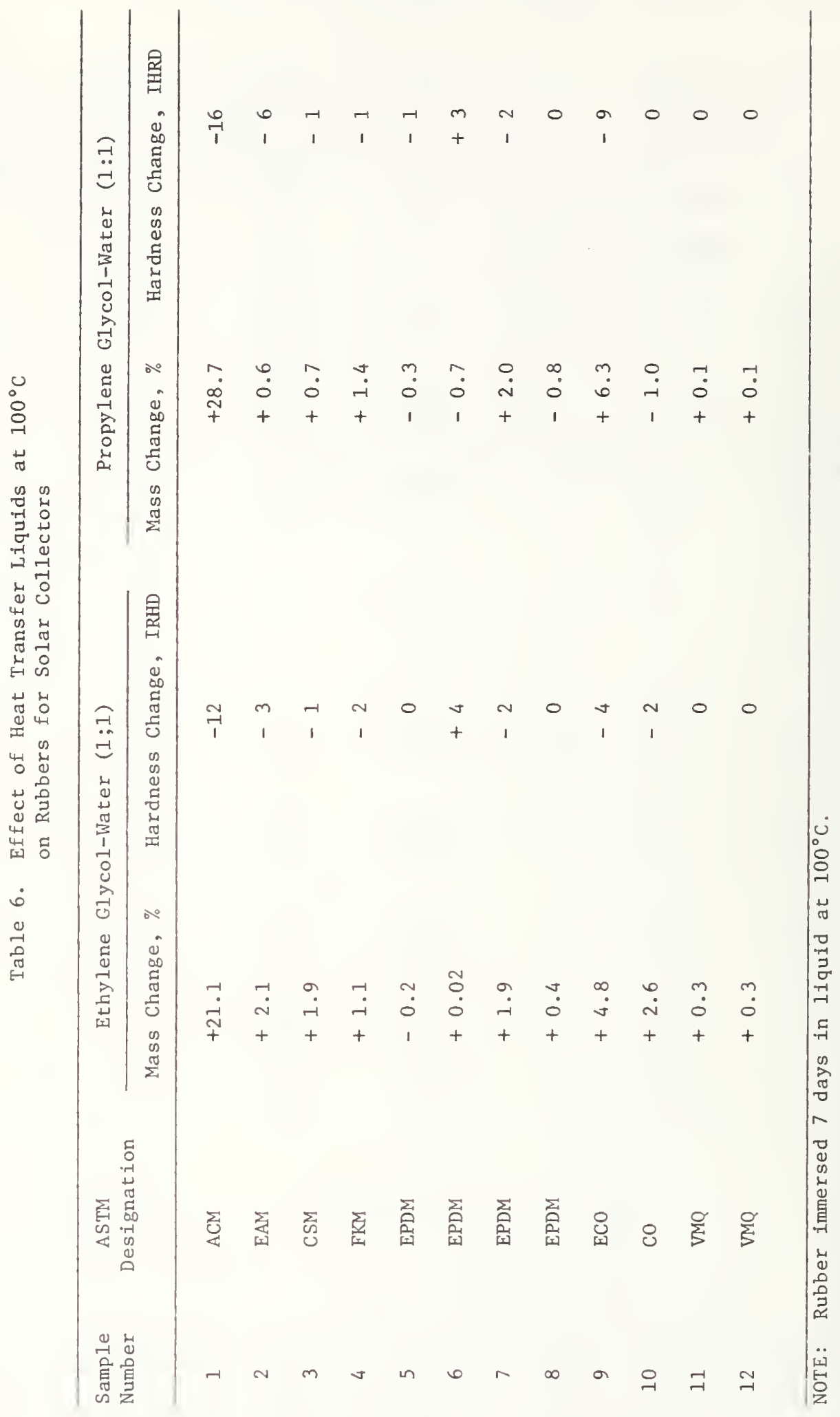




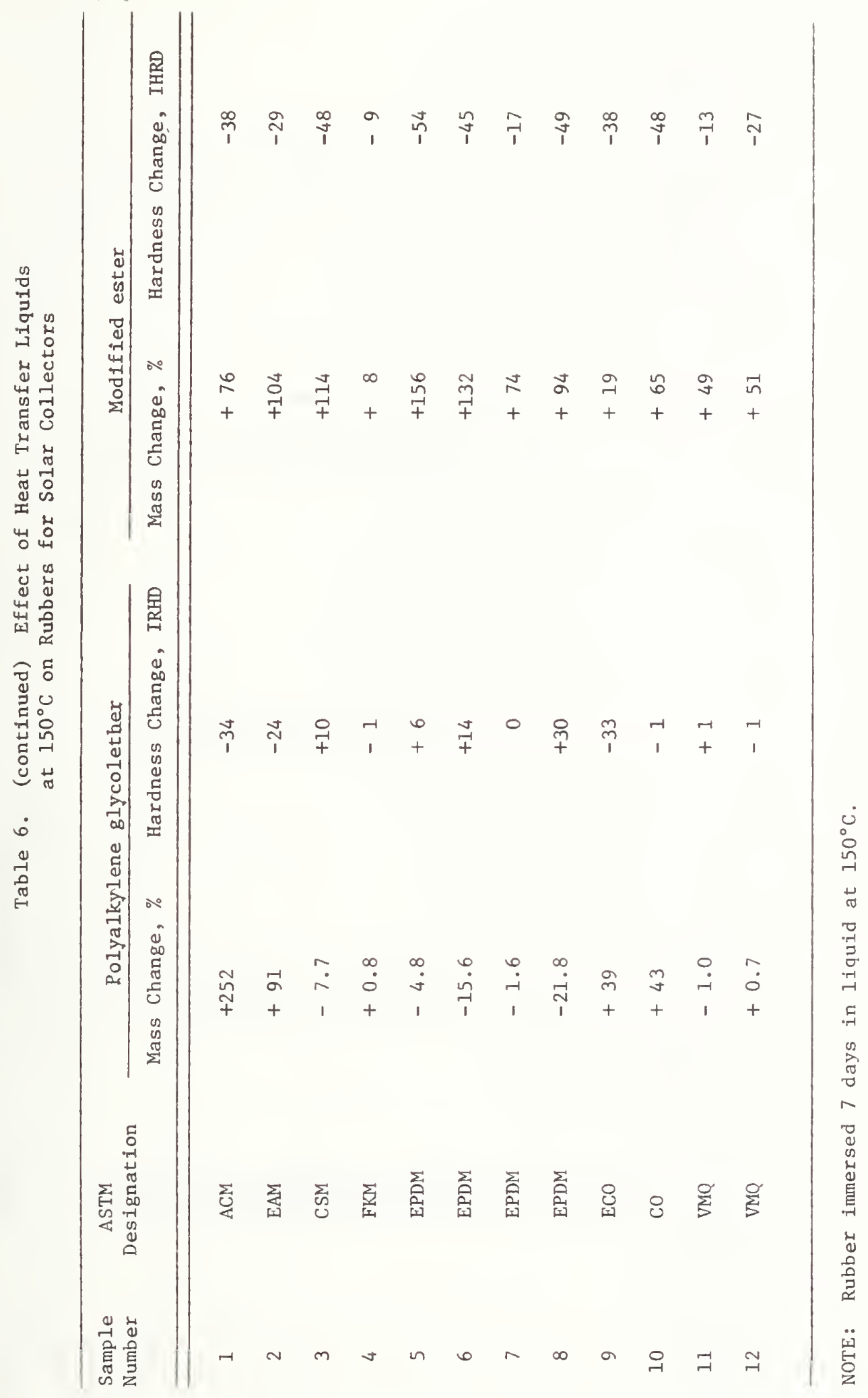




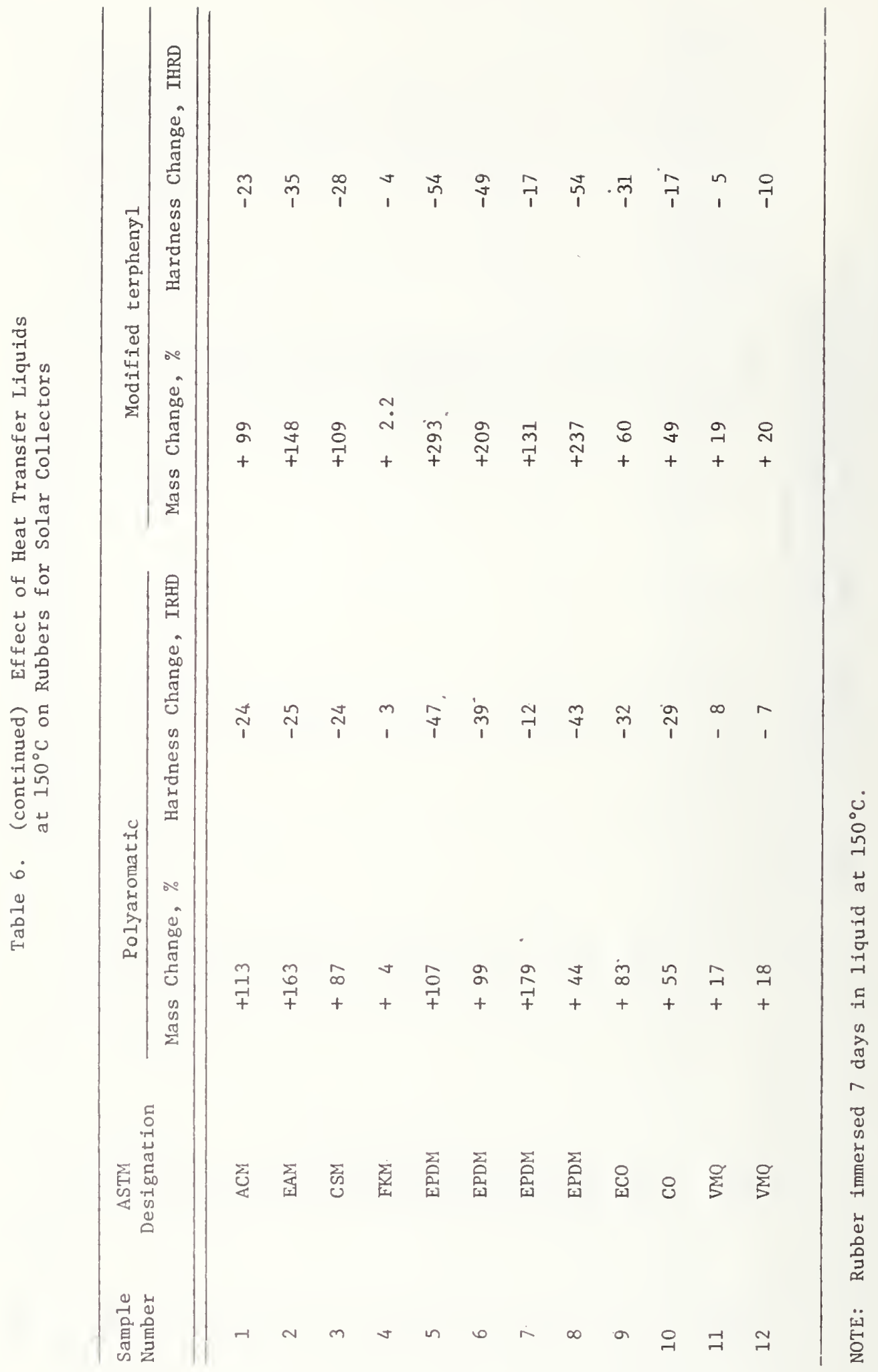




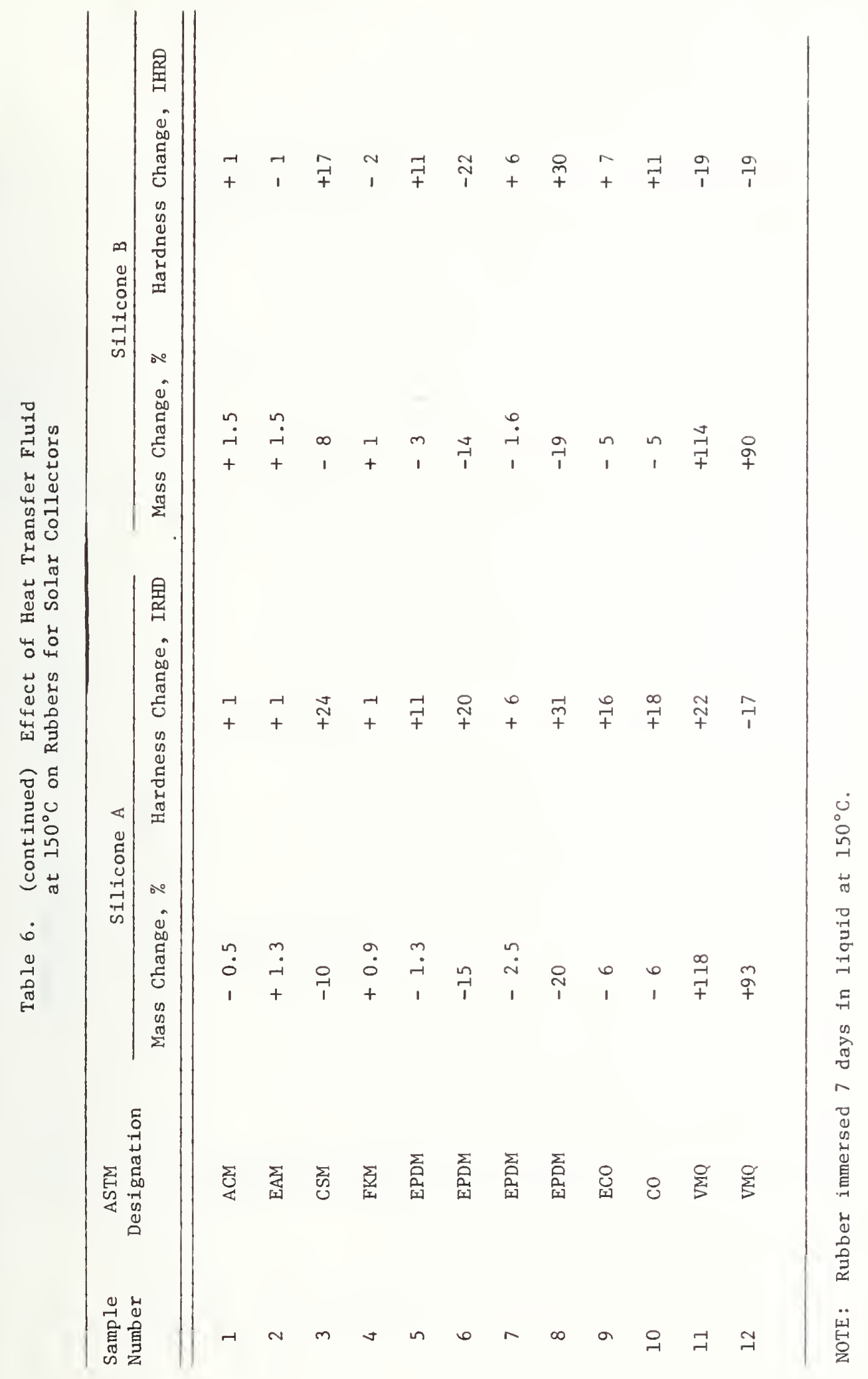




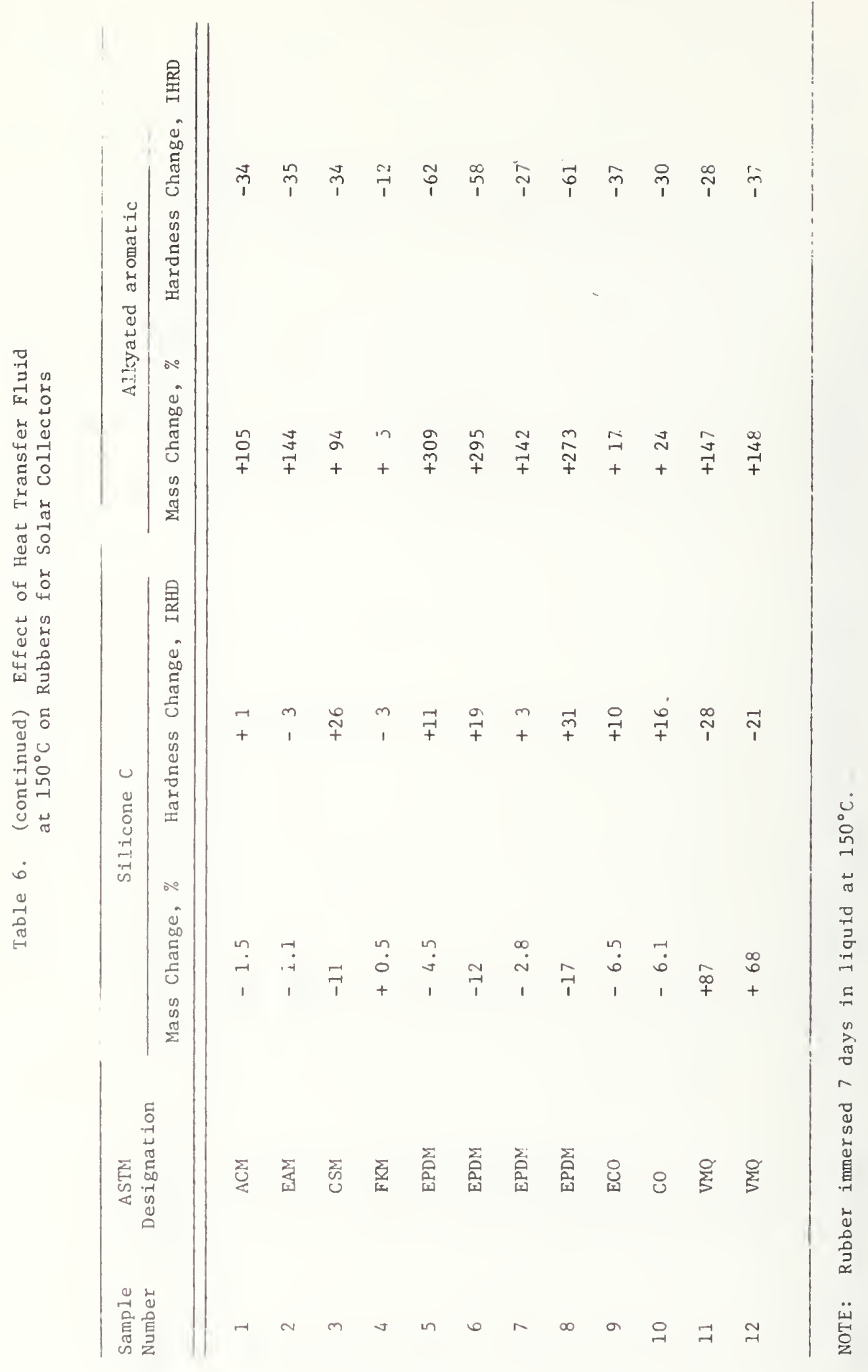




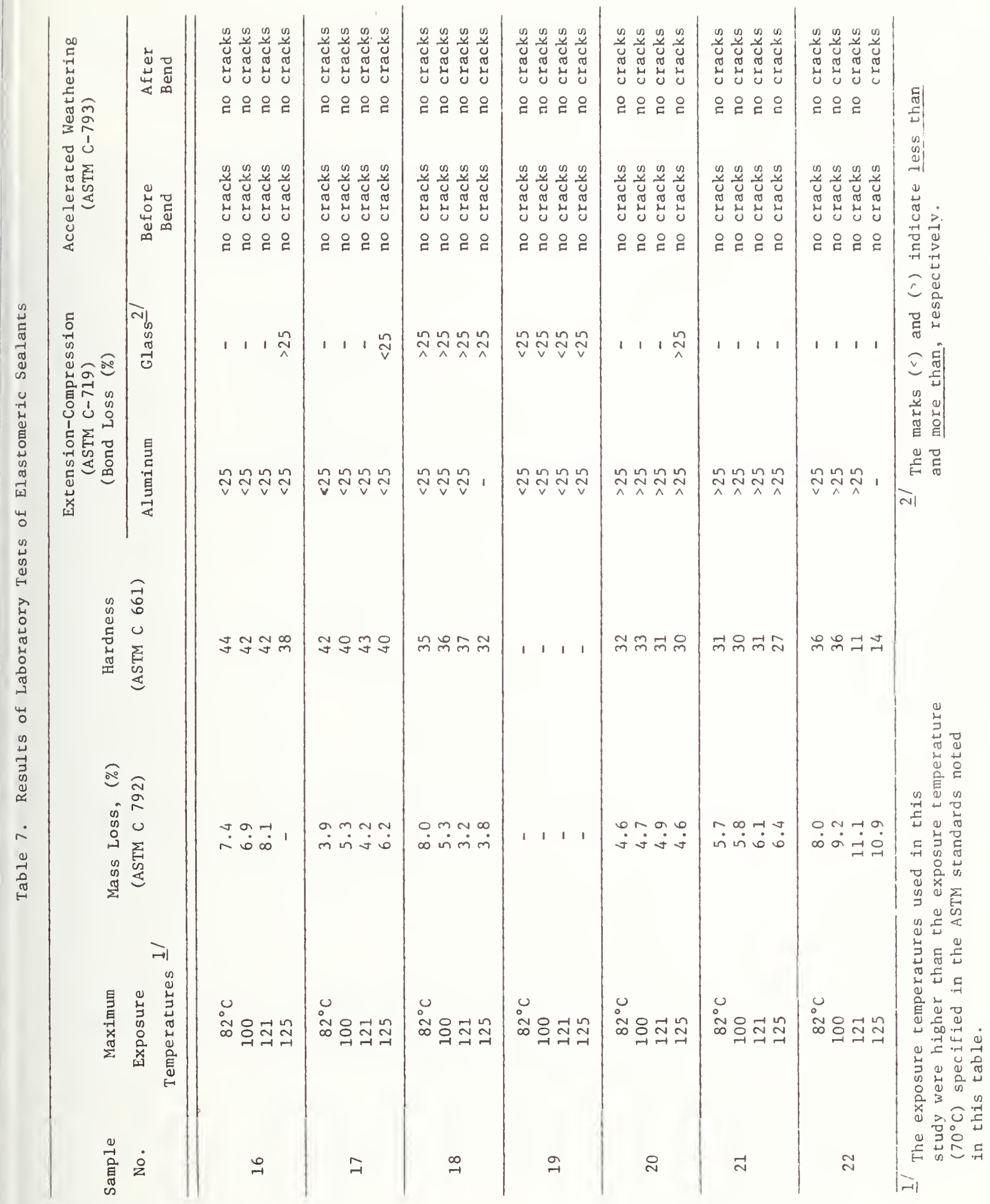




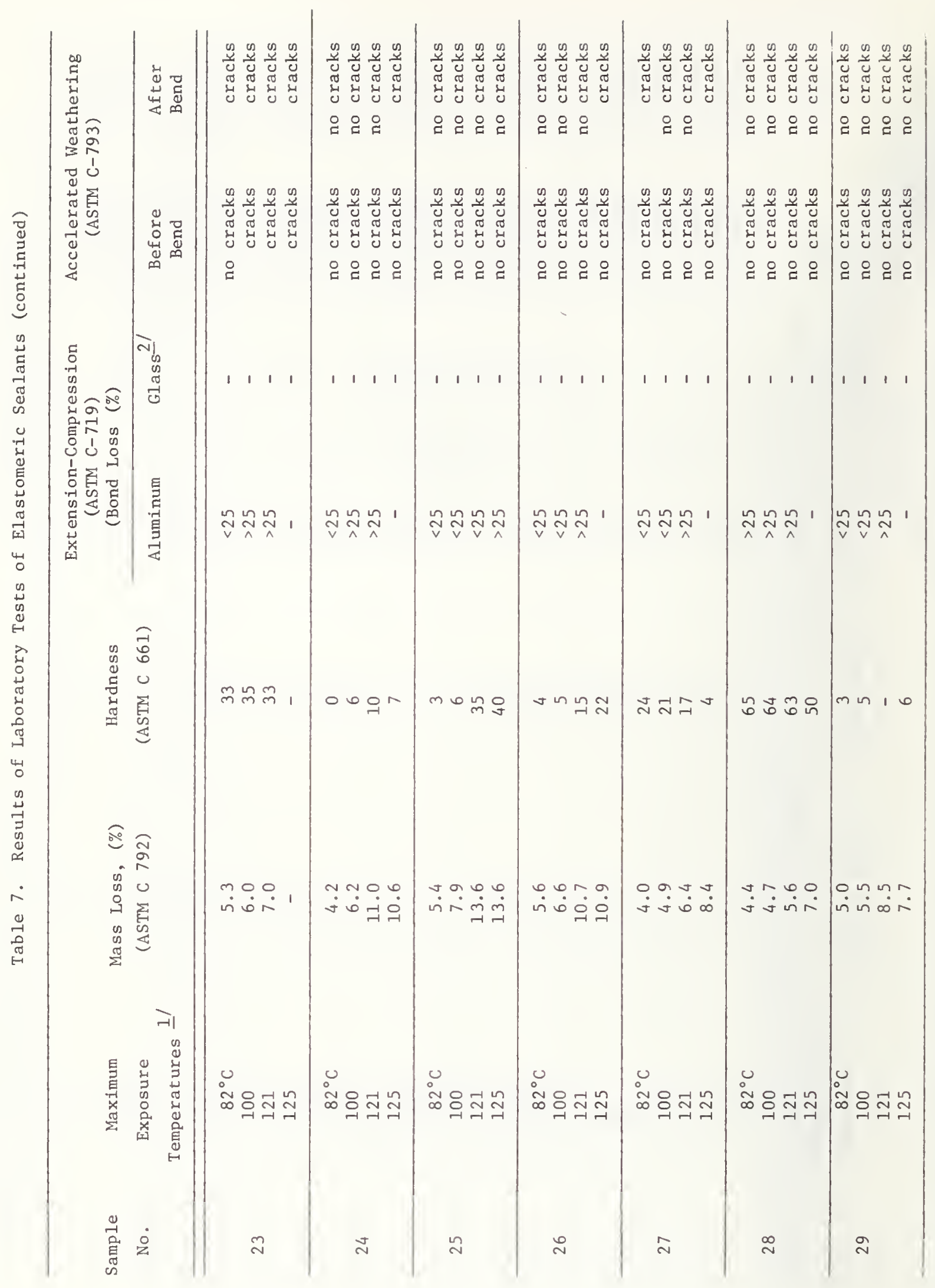




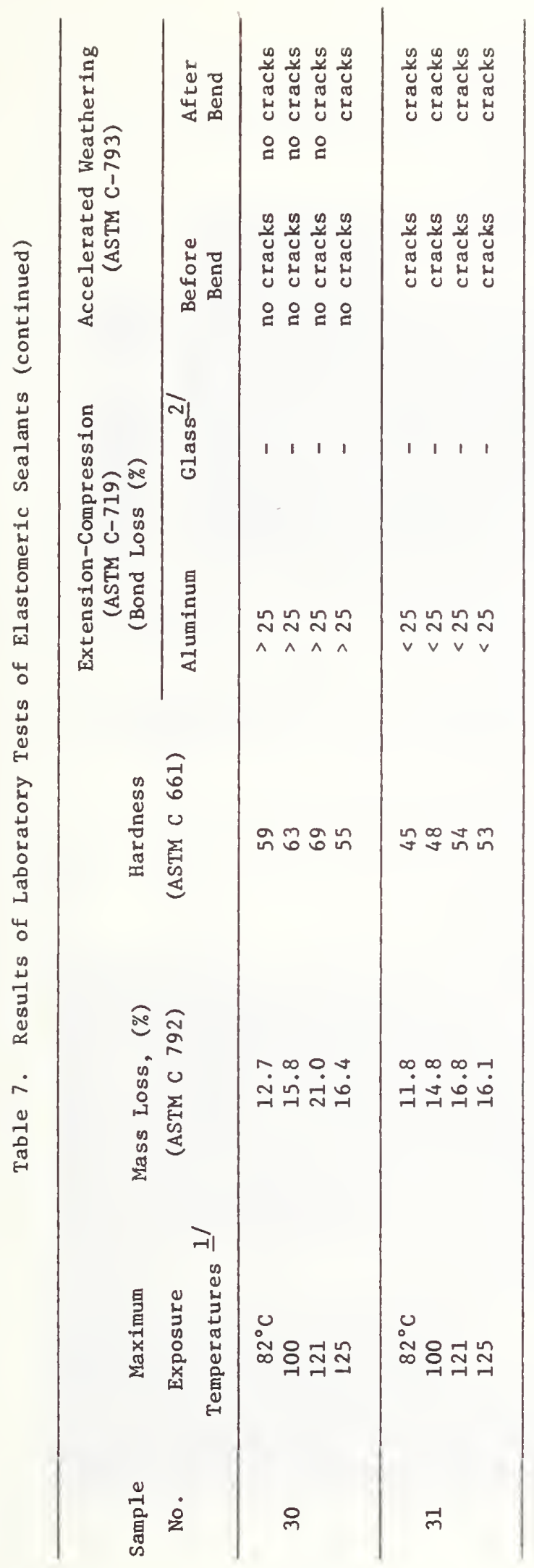




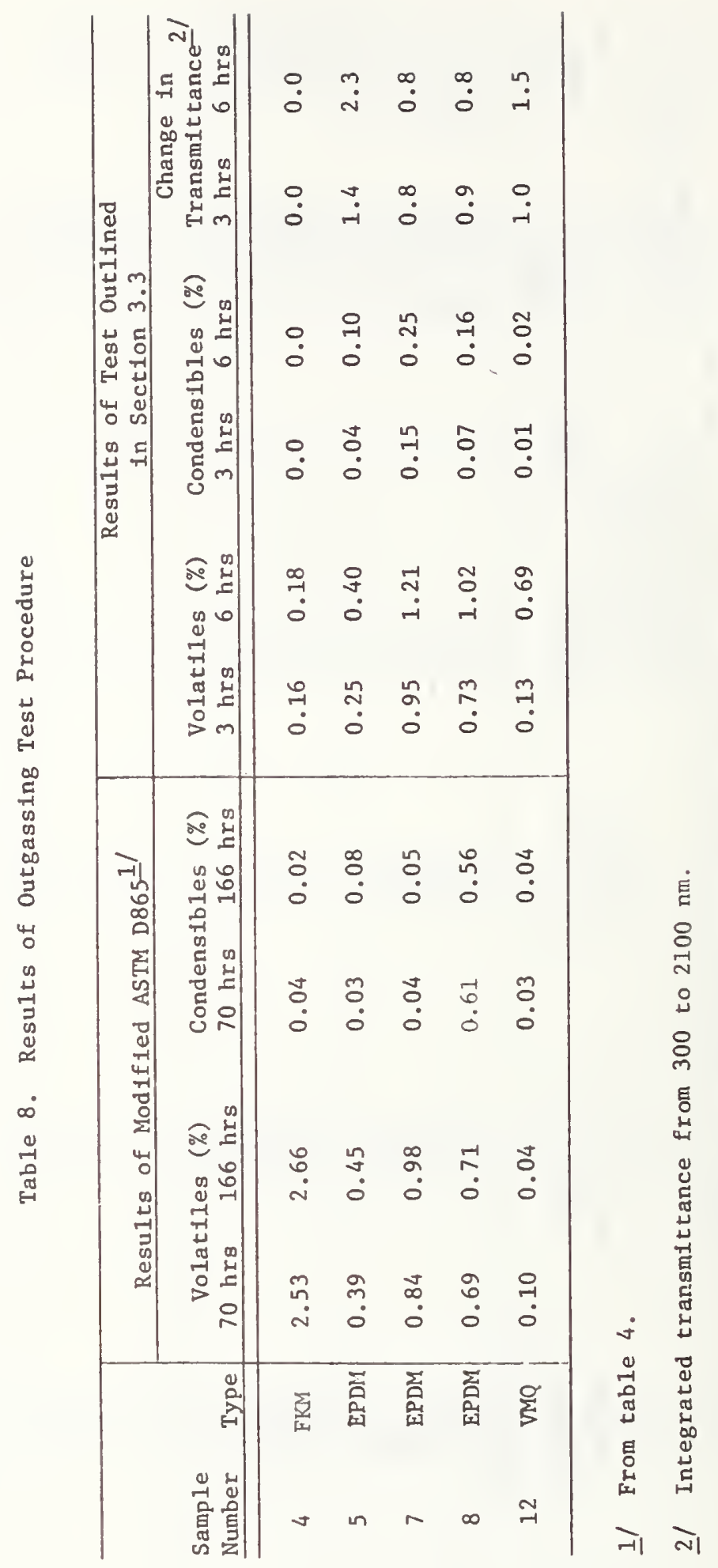




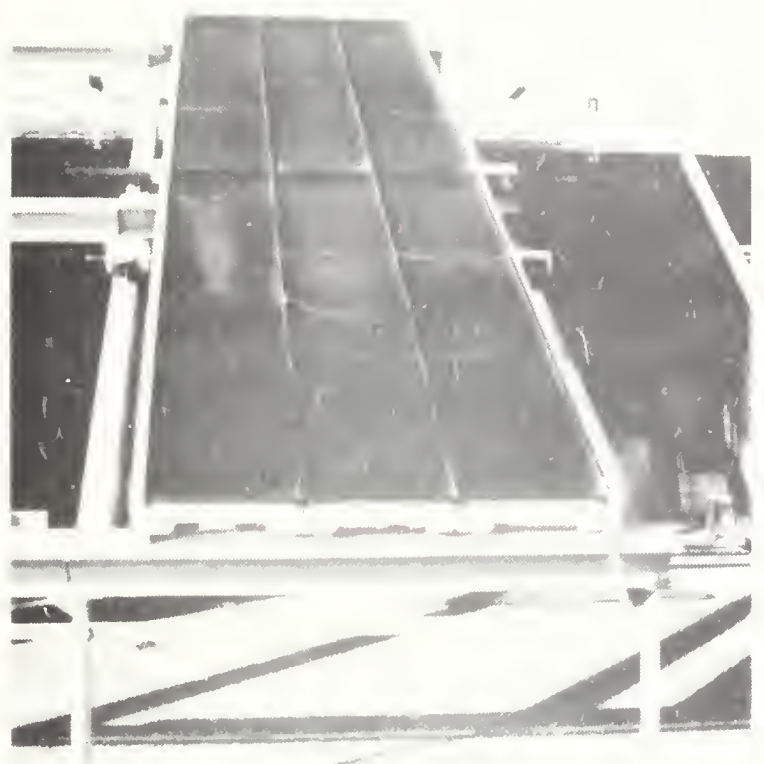

Figure 1. Fogging of Collector Cover Plates by Outgassing Products.

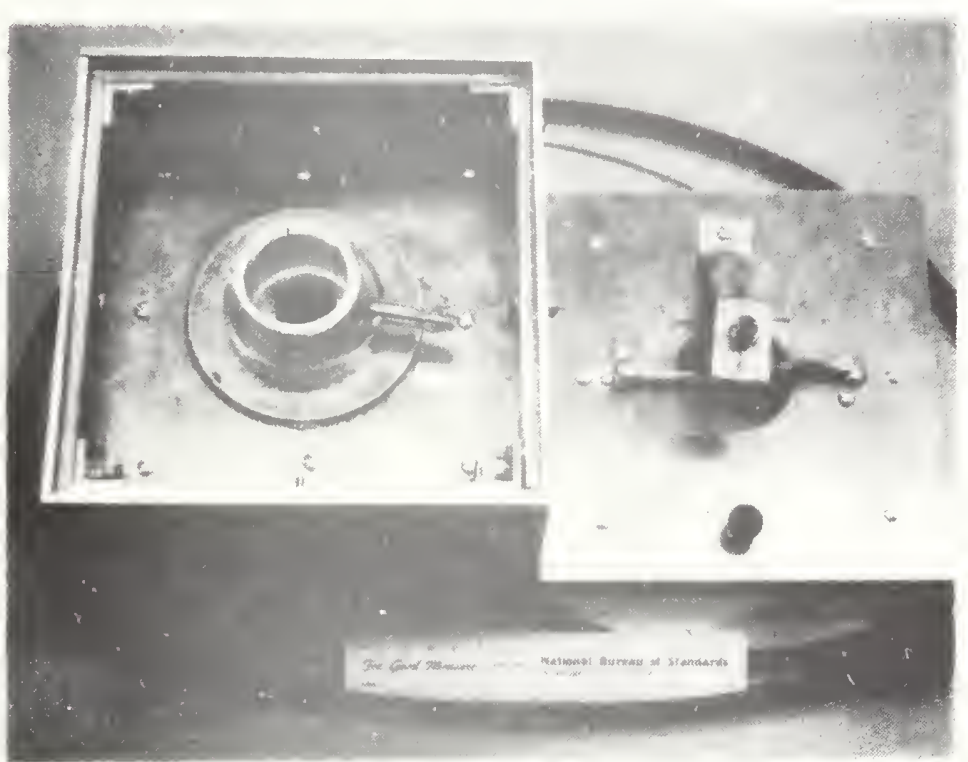

Figure 2. Components of the Outgassing Test Apparatus. 


\section{APPENDIX A \\ Proposed Standard Specification for Rubber Seals Used in Flat-Plate Solar Collectors}

1. Scope

1.1 This specification gives the general requirements for materials used in rubber seals of flat-plate solar collectors except vertically mounted passive collectors. Particular applications may necessitate other requirements which would take precedence over these requirements when specified.

1.2 Design requirement pertains only to permissible deflections of the rubber during thermal expansion or contraction of the seal in use and the tolerances in dimensions of molded and extruded sea $1 \mathrm{~s}$.

1.3 This specification does not include requirements pertaining to the fabrication or installation of the seals.

2. Applicable Documents

2.1 ASTM Standards

C661 Test for Indentation Hardness of Elastomeric Type Sealants by means of a Durometer.

C717 Definition of Terms Relating to Building Seals

C719 Test for Adhesion and Cohesion of Elastomeric Joint Sealants under Cyclic Movement

D395 Test for Rubber Property - Compression Set

D412 Test for Rubber Properties in Tension

D865 Test for Rubber Deterioration by Heating in a Test Tube

D1149 Test for Rubber Deterioration - Surface Ozone Cracking in a Chamber (Flat Specimen)

D1229 Test for Rubber Property - Compression Set at Low Temperature 
D1415

Test for Rubber Property - International Hardness

D1566 Definition of Terms Relating to Rubber

D2137 Test for Rubber Property - Brittleness Polnt of Flexible

Polymers and Coated Fabrics

D2240 Test for Rubber Property - Durometer Hardness

D3182 Rubber - Materials, Equipment and Procedures for Mixing

Standard Compounds and Preparing Standard Vulcanized Sheets

D3183

Rubber - Preparation of Pleces for Test from Other Than

Strndard Vulcanized Sheets

2.2 Other Standards

RMA Handbook - Rubber Products, Molded-Extruded-Lathe Cut-Cellular

3. Classification

3.1 Types

Type C, Intended for use in cold climates (below $-10^{\circ} \mathrm{C}$ in winter)

Type $W$, intended for use in warm climates (above $-10^{\circ} \mathrm{C}$ in winter)

3.2 Grades

Grade designations represent differing degrees of hardness as follows:

Grade 2, Hardness of $20 \pm 5$

Grade 3, Hardness of $30 \pm 5$

Grade 4, Hardness of $40 \pm 5$

Grade 5, Hardness of $50 \pm 5$

Grade 6, Hardness of $60 \pm 5$

Grade 7, Hardness of $70 \pm 5$

Grade 8 , Hardness of $80 \pm 5$

Note 1 - The grade to be used in a particular application depends on the design of the seal and must be specifled by the designer. 


\subsection{Classes}

Seals shall be classified as follows:

Class PS, Preformed rubber seal

Class SC, Sealing compound

Note 2 - Class SC material should not be used in designs where the seal is under mechanical stress.

4. Terminology

4.1 Definitions of terms are given in ASTM C717 and D1566

5. Materials

5.1 Seals shall be made from rubber formulations that are impervious to ultraviolet light and when vulcanized conform to the requirements in Section 6.

6. Requirements

6.1 Class PS material shall conform to the requirements given in Table 1.

6.2 Class SC material shall conform to the requirements given in Table 2.

\section{Dimensions}

7.1 The design of the seal shall not permit the rubber to deflect more than $25 \%$ in any direction during thermal expansion and contraction of the solar collector.

Note 3 - If the thermal coefficient of Iinear expansion for the rubber is not known, a value of $0.0003 / \mathrm{K}$ may be assumed for design purposes. 7.2 The tolerances in dimensions of molded seals shall conform to RMA 
A3-F3-T.032 as given for molded products in the RMA Handbook. Tolerances on any critical dimension shall conform to RMA A2-F3-T.032 in that handbook.

7.3 The tolerances in dimensions of extruded seals shall conform to RMA A2-F3 given for extruded products in the RMA Handbook.

8. Workmanship

8.1 Class PS seals shall be free of blisters, checks, cracks, and other Imperfections that can affect their ability to make or maintain a water-tight seal.

8.2 Class SC material shall be uniform in composition and be free of defects that may affect serviceability.

9. Sampling and Inspection

9.1 Class PS material. Manufacturers of preformed seals may use their quality control systems for production inspection to assure the seals conform with this specification, provided appropriate records are kept. In case of dispute regarding the quality of a delivered product, a sample of five seals shall be taken from the lot and tested for compliance with this specification. If one of the five seals does not conform, a second sample of five seals may be taken and tested. If two or more of the ten seals do not conform, the lot may be rejected.

9.2 Class SC material. Manufacturers may use their quality control systems to assure production conforms with this specification. In case of dispute regarding the quality of a delfvered product, five test sheets and five adhesion specimens shall be prepared; preferably from five different packages, in accordance with the instructions supplied with the sealing material. If one of the five sheets or adhesion

$$
A-4
$$


specimens does not conform, an additional five sheets or adhesion spectmens may be prepared and tested. If two or more of the ten sheets or adhesion specimens do not conform, the lot may be refected.

\section{Testing}

10.1 Class PS material. Specimens shall be prepared as prescribed in ASTM D3183 and tested in accordance with the methods of test given in Table 1. For control of production, specimens may be taken from standard test sheets prepared in accordance with ASTM D3182, using the same unvulcanized materlal used to prepare the seals and vulcanizing the materlal at the same temperature used for the seals to an equivalent state of vulcanization.

10.2 Class SC material. Five sheets approximately 150 by 150 by $2 \mathrm{~mm}$ ( 6 by 6 by 0.08 in) shall be prepared in accordance with instructions supplied with the sealing material. Also, five adhesion specimens shall be prepared In accordance with ASTM C719. Preferably, each sheet and adhesion specimen should be prepared from materlal in a different container. Condition the sheets and adhesion specimens for 14 days at a temperature of $23^{\circ} \mathrm{C}$ and relative humidity of 50 percent. Test the material in accordance with the methods of test given in Table 2 .

10.3 Volatiles lost shall be determined from the difference in mass of the specimens before and after heating for $166 \mathrm{~h}$ at the temperature given in Table 1 or 2 and as prescribed in ASTM D865.

10.4 Volatiles condensible at $23^{\circ} \mathrm{C}$ shall be determined from the difference In mass of the outlet tubes (ASTM D865) before and after heating the specimens for $166 \mathrm{~h}$ at the temperature given in Table 1 or 2. The exposed portion of the outlet tube shall be cooled, if necessary, with a stream

$$
A-5
$$


of air to maintain a temperature of $23 \pm 2^{\circ} \mathrm{C}$. If any volatiles condense on the inlet tube or other parts of the apparatus, the mass of this condensed materlal shall be added to the mass of the material on the outlet tube.

11. Marking

11.1 Name, brand or trademark of the manufacturer.

11.2 Type and Grade.

11.3 Compliance with this standard, ASTM DXXXX.

11.4 Other information required by manufacturer or purchaser.

11.5 Marking may be on efther seal, packaging, label, or tag.

12. Packaging

12.1 Material shall be protected by suitable packaging to prevent damage during shipment or storage prior to Installation in solar collector. 
Table 2. Requirements for Class SC Material

Used to Seal Flat-Plate Solar Collectors

\begin{tabular}{|c|c|c|c|c|}
\hline \multirow[t]{2}{*}{ Property } & \multicolumn{3}{|c|}{ Grade } & \multirow[t]{2}{*}{ Method } \\
\hline & 2 & 3 & 4 & \\
\hline Ultimate Elongation-\% min & 200 & 150 & 100 & D412 \\
\hline $\begin{array}{l}\text { Resistance to Heating } \\
\quad\left(166 \mathrm{~h} \text { at } 125^{\circ} \mathrm{C}\right)\end{array}$ & & & 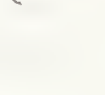 & D865 \\
\hline $\begin{array}{l}\text { Hardness Change, max } \\
\text { Ultimate Elongation }\end{array}$ & 10 & 10 & 10 & C661 \\
\hline $\begin{array}{l}\text { Change, } \% \max \\
\text { Tensile Strength }\end{array}$ & 30 & 30 & 30 & D412 \\
\hline Change, \% max & 20 & 20 & 20 & D412 \\
\hline $\begin{array}{l}\text { Volatiles Lost, } \% \max \\
\text { Volatiles Condensible, } \\
\% \max \end{array}$ & $\begin{array}{c}1 \\
0.1\end{array}$ & 0.1 & $\begin{array}{c}1 \\
0.1\end{array}$ & $\begin{array}{l}\text { See } 10.3^{\text {a) }} \\
\text { See } 10.4^{a)}\end{array}$ \\
\hline Resistance to Ozone & & & & D1149 \\
\hline $100 \mathrm{mPa}, 166 \mathrm{~h}$ at $40^{\circ} \mathrm{C}$ & & Crack & & \\
\hline $\begin{array}{l}\text { Resistance to Low } \\
\text { Temperature }\end{array}$ & & & & D2137 \\
\hline Type $\mathrm{C}$ on $1 \mathrm{y},{ }^{\circ} \mathrm{C} \max$ & -40 & -40 & -40 & \\
\hline Adhesion loss $\left.\left(-\mathrm{cm}^{2} \max \right)^{b}\right)$ & 9 & 9 & 9 & C719 c) \\
\hline
\end{tabular}
a) This test is not required if the design precludes condensing of the volatiles on the cover plate(s) of the solar collector.
b) The combined loss in bond and cohesion areas for the three specimens tested shall not exceed $9 \mathrm{~cm}^{2}$.
c) The temperature in 6.3 of ASTM C719 shall be modified to $125^{\circ} \mathrm{C}$. 


\section{Proposed Standard Specification for Rubber Seals Contacting Liquids in Solar Energy Systems}

1. Scope

1.1 This specification gives the general requirements for materials used in preformed rubber seals that contact the circulating liquid in solar energy systems. Particular applications may necessitate other requirements which would take precedence over these requirements when specified.

1.2 This specification does not include requirements pertaining to the design, fabrication or installation of the seals.

\section{Applicable Documents}

2.1 ASTM Standards

D395 Test for Rubber Property - Compression Set

D412 Test for Rubber Properties in Tension

D471 Test for Rubber Property - Effect of Liquids

D865 Test for Rubber Deterioration by Heating in a Test Tube

D1149 Test for Rubber Deterioration - Surface Ozone Cracking in a Chamber (Flat Specimen)

D1229 Test for Rubber Property - Compression Set at Low Temperature

D1349 Rubber - Standard Temperatures and Atmospheres for Testing and Conditioning

D1415 Test for Rubber Property - International Hardness

D1566 Definition of Terms Relating to Rubber

D2137 Test for Rubber Property - Brittleness Point of Flexible Polymers and Coated Fabrics 
D3182 Rubber - Materials, Equipment and Procedures for Mixing Standard Compounds and Preparing Standard Vulcanized. Sheets

D3183 Rubber - Preparation of Pieces for Test from Other Than Standard Vulcanized Sheets

2.2 Other Standards

RMA Handbook - Rubber Products, Molded-Extruded-Lathe Cut-Cellular

3. Classification

3.1 Types

Type $\mathrm{C}$, intended for use in cold climates (below $-10^{\circ} \mathrm{C}$ in winter)

Type $W$, intended for use in warm climates (above $-10^{\circ} \mathrm{C}$ in winter)

3.2 Grades

Grade designations represent differing degrees of hardness as follows:

Grade 3, Hardness of $30 \pm 5$

Grade 4, Hardness of $40 \pm 5$

Grade 5, Hardness of $50 \pm 5$

Grade 6; Hardness of $60 \pm 5$

Grade 7, Hardness of $70 \pm 5$

Grade 8 , Hardness of $80^{\circ} \pm 5$

Note 1 - The grade to be used in a particular application depends on the design of the seal and must be specifled by the designer.

\subsection{Classes}

Seals shall be classified as follows:

Class A, Seals for use with aqueous liquids

Class $N$, Seals for use with non-aqueous liquids

Note 2 - Aqueous 11quids include water and antifreeze solutions. 
4. Terminology

4.1 Definitions of terms are given in ASTM D1566

5. Ordering Information

5.1 Orders for seals under this specification shall include the following information:

5.1.1 Reference to this Standard: ASTM Dxxxx

5.1.2 Type, Grade and class

5.1.3 Design and dimensions of sea1

5.1.4 Contacting Iiquid

5.1.5 Maximum service temperature

6. Requirements

6.1 Seals shall be vulcanized from suitable rubber formulations and conform to the requirements given in Tables 1 and 2 .

7. Dimensions

7.1 The tolerances in dimensions of molded seals shall conform to "RMA A3-F3-T.032 as given for molded products in the RMA Handbook. Tolerances on any critical dimension shall conform to RMA A2-F3-T.032 in that Handbook.

7.2 The tolerances in dimensions of extruded seals shall conform to RMA A2-F3 given for extruded products in the RMA Handbook.

8. Workmanship

8.1 Seals shall be free of blisters, checks, cracks, and other imperfections that can affect their ability to make or maintain a liquid-tight seal.

9. Sampling and Inspection

9.1 Manufacturers of seals may use their quality control systems for production Inspection to assure the seals conform with this specification, provided appropriate records are kept. In case of dispute regarding the quaitity of a delivered product, a sample of five seals shall be taken from the lot and tested for compliance with this specification. If one of the five seals does not conform, a second sample of five seals may be taken and tested. If two or more of the ten seals do not conform, the lot may be rejected. 


\section{Testing}

10.1 Specimens shall be prepared as prescribed in ASTM D $30 \%$ and tested in accordance with the methods of test given in 10.2. For control of production, specimens may be taken from standard test sheets prepared in accordance with ASTM D3182, using the same unvulcanized material used to prepare the seals and vulcanizing the material at the same temperature used for the seals to an equivalent state of vulcanization.

10.2 Ultimate elongation shall be determined in accordance with ASTM D412. Other requirements shall be determined in accordance with the ASTM methods specified in Table 2.

10.3 Class A seals shall be tested for heat resistance and compression set at a temperature of $125^{\circ} \mathrm{C}$ and for resistance to liquids at a temperature of $100^{\circ} \mathrm{C}$. 10.4 Class $\mathrm{N}$ seals shall be tested for heat resistance and compression set at the standard test temperature in ASTM D1349 that is between $25^{\circ} \mathrm{C}$ and $49^{\circ} \mathrm{C}$ above the maximum service temperature, and for resistance to liquids at the standard test temperature that is between $1^{\circ} \mathrm{C}$ and $25^{\circ} \mathrm{C}$ above the maximum service temperature. The standard test temperatures shall not be less than those for Class A seals. Above $125^{\circ} \mathrm{C}$, the standard test temperatures are: 150, 175, 200, 225 and $250^{\circ} \mathrm{C}$.

10.5 The liquid used for tests in accordance with ASTM D471 shall be the one used in service for the particular heat transport system.

11. Marking

11.1 Name, brand or trademark of the manufacturer.

11.2 Type and Grade.

11.3 Compliance with this standard, ASTM DXXXX.

11.4 Other information required by manufacturer or purchaser.

11.5 Marking may be on either seal, packaging, label, or tag.

12. Packaging

12.1 Material shall be protected by suitable packaging to prevent damage during shipment or storage prior to installation in solar collector. 
Table 1. Elongation Requirements for Rubber Seals in Liquid Heat-Transport Systems

\begin{tabular}{cc} 
Grade & $\begin{array}{c}\text { Ultimate Elongation } \\
\text { percent, minimum }\end{array}$ \\
\cline { 2 - 2 } 3 & 350 \\
4 & 300 \\
5 & 250 \\
6 & 200 \\
7 & 150 \\
8 & 100
\end{tabular}

Table 2. Other Requirements for Rubber Seals in Liquid Heat-Transport Systems

\section{Property}

Compression Set

High temperature ${ }^{a}$

Low temperatureb

Resistance to Heating ${ }^{c}$

Hardness change
Ultimate elongation

change

Resistance to Ozoned

Resistance to Low

Temperature $e^{e}$

Resistance to Liquidf

Volume change

Hardness change
Unit

\% 30 maximum

$\% 60$ maximum

IRHD

$\%$ of

origlnal

- -

${ }^{\circ} \mathrm{C}$

$\%$

IRHD
Requirement

10 maxirnum

30 maximum

no cracking

-40 maximum

+40 to -10

$\pm 10$

\section{ASTM Method}

D395, Method B

D1229

D1415

D412

D1149

D2137

D471

D1415

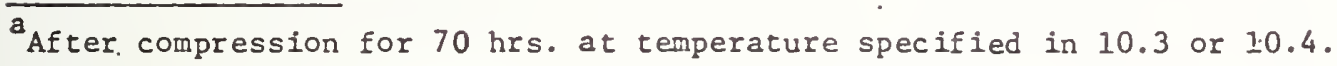

${ }^{b}$ After compression for 166 hrs. at $-10^{\circ} \mathrm{C}$. Set shall be measured at $10 \mathrm{sec}$. after force is release. Lubricated plates or polytetrafluoroethylene film is recommended If the rubber adheres to the metal plates during test.

${ }^{c}$ Condition for 166 hrs. at temperature specified in 10.3 or 10.4 .

$\mathrm{d}_{\text {This }}$ requirement does not apply to seals that are not exposed to outside atmospheres.

E This requirement applies to Type $C$ seals only.

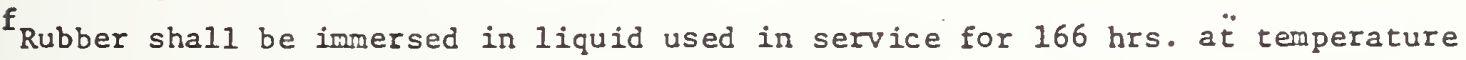
speclfied in 10.3 or 10.4 . 


\section{APPENDIX C}

Proposed Standard Specification for Rubber

Seals Used in Solar Collectors

(other than Flat-Plate Collectors)

\section{Scope}

1.1 This specification gives the general requirements for materials used in rubber seals of vertically mounted passive solar collectors and curved concentrating collectors. Particular applications may necessitate other requirements which would take precedence over these requirements when specified.

1.2 Design requirement pertains only to permissible deflections of the rubber during thermal expansion or contraction of the seal in use and the tolerances in dimensions of molded and extended seals.

1.3 This specification does not include requirements pertaining to the fabrication or installation of the seals.

2. Applicable Documents

2.1 ASTM Standards

C661 Test for Indentation Hardness of Clastomeric Type Sealants by means of a Durometer.

C717 Definition of Terms Relating to Building Seals

C719 Test for Adhesion and Cohesion of Elastomeric Joint Sealants under Cyclic Movement

D395 Test for Rubber Property - Compression Set

D412 Test for Rubber Deterioration by Heating in a Test Tube

D1149 Test for Rubber Deterioration - Surface Ozone Cracking in a Chamber (Flat Specimen)

D1229 Test for Rubber Property - Compression Set at Low Temperature 
D1415 Test for Rubber Property - International Hardness

D1566 Definition of Terms Relating to Rubber

D2137 Test for Rubber Property - Brittleness Point of Flexible

Polymers and Coated Fabrics

D2240 Test for Rubber Property - Durometer Hardness

D3182 Rubber - Materials, Equipment and Procedures for Mixing

Standard Compounds and Preparing Standard Vulcanized Sheets

D3183 Rubber - Preparation of Pieces for Test from Other Than

Standard Vulcanized Sheets

2.2 Other Standards

RMA Handbook - Rubber Products, Molded-Extruded-Lathe Cut-Cellular

3. Classification

3.1 Types

Type $\mathrm{C}$, intended for use in cold climates (below $-10^{\circ} \mathrm{C}$ in winter)

Type $\mathrm{W}$, intended for use in warm climates (above $-10^{\circ} \mathrm{C}$ in winter)

3. 2 Grades

Grade designations represent differing degrees of hardness as follows:

Grade 2, Hardness of $20 \pm 5$

Grade 3, Hardness of $30 \pm 5$

Grade 4, Hardness of $40 \pm 5$

Grade 5, Hardness of $50 \pm 5$

Grade 6, Hardness of $60 \pm 5$

Grade 7, Hardness of $70 \pm 5$

Grade 8 , Hardness of $80 \pm 5$

Note 1 - The grade to be used in a particular application depends on the design of the seal and must be specified by the designer. 


\subsection{Classes}

Seals shall be classified as follows:

Class PS, Preformed rubber seal

Class SC, Sealing compound

Note 2 - Class SC material should not be used in designs where the seal is under mechanical stress.

\section{Terminology}

4.1 Definitions of terms are given in ASTM C717 and D1566

5. ordering Information

5.1 Orders for seals under this specification shall include the following information:

5.1.1 Reference to this Standard: ASTM Dxxxx

5.1.2 Type, Grade and Class

5.1.3 Design and dimensions of seal

5.1.4 Maximum service temperature

5.1.5 Quantity

6. Materials

6.1 Seals shall be made from rubber formulations that are impervious to ultraviolet light and when vulcanized conform to the requirements in Section $\dot{0}$.

7. Requirements

7.1 Class PS material shall conform to the requirements given in Table 1.

7.2 Class SC material shall conform to the requirements given in Table 2.

\section{Dimensions}

8.1 The design of the seal shall not permit the rubber to deflect more than $25 \%$ in any direction during thermal expansion and contraction of the solar collector. 
Note 3 - If the thermal coefficlent of linear expansion for the rubber is not known, a value of $0.0003 / \mathrm{K}$ may be assumed for design purposes. 8.2 The tolerances in dimensions of molded seals shall conform to RMA A3-F3-T.032 as given for molded products in the RMA Handbook. Tolerances on any critical dimension sha11 conform to RMA A2-F3-T.032 in that handbook.

8.3 The tolerances in dimensions of extruded seals shall conform to RMA A2-F3 given for extruded products in the RMA Handbook.

9. Workmanship

9.1 Class PS seals shall be free of blisters, checks, cracks, and other imperfections that can affect their ability to make or maintain a water-tight seal.

9.2 Class SC material shall be uniform in composition and be free of defects that may affect serviceability.

10. Sampling and Inspection.

10.1 Class PS materia1. Manufacturers of preformed seals may use their quality control systems for production inspection to assure the seals conform with this specification, provided appropriate records are kept. In case of dispute regarding the quality of a delivered product, a sample of five seals shall be taken from the lot and tested for compliance with this specification. If one of the five seais does not conform, a second sample of five seals may be taken and tested. If two or more of the ten seals do not conform, the lot may be rejected.

10.2 Class SC material. Manufacturers may use their quality control systems to assure production conforms with this specification. In case of dispute regarding the quality of a delivered product, five test sheets and five adhesion specimens shall be prepared, preferably from five different packages, in accordance with the instructions supplied with the sealing material. If one of the five sheets or adhesion 
specimens does not conform, an additional five sheets or adhesion specimens may be prepared and tested. If two or more of the ten sheets or adhesion specimens do not conform, the lot may be rejected.

11. Testing

11.1 Class PS material. Specimens shall be prepared as prescribed in ASTM D3183 and tested in accordance with the methods of test given in Table 1. For control of production, specimens may be taken from standard test sheets prepared in accordance with ASTM D3182, using the same unvulcanized materfal used to prepare the seals and vulcanizing the material at the same temperature used for the seals to an equivalent state of vulcanization.

11.2 Class SC material. Five sheets approximately 150 by 150 by $2 \mathrm{~mm}$ ( 6 by 6 by 0.08 in) shall be prepared in accordance with instructions supplied with the sealing material. Also, five adhesion specimens shall be prepared in accordance with ASTM C719. Preferably, each sheet and adhesion specimen should be prepared from material in a different container. Condition the sheets and adhesion specimens for 14 days at a temperature of $23^{\circ} \mathrm{C}$ and relative humidity of 50 percent. Test the material in accordance with the methods of test given in Table 2.

11.3 Volatiles lost shall be determined from the difference in mass of the specimens before and after heating for $166 \mathrm{~h}$ at the temperature given in Table 1 or 2 and as prescribed in ASTM D865.

11.4 Volatiles condensible at $23^{\circ} \mathrm{C}$ shall be determined from the difference in mass of the outlet tubes (ASTM D865) before and after heating the specimens for $166 \mathrm{~h}$ at the temperature given in Table 1 or 2 . The exposed portion of the outlet tube shall be cooled, if necessary, with a stream 
of air to maintain a temperature of $23 \pm 2{ }^{\circ} \mathrm{C}$. If any volatiles condense on the inlet tube or other parts of the apparatus, the mass of this condensed material shall be added to the mass of the material on the outlet tube.

12. Marking

12.1 Name, brand or trademark of the manufacturer.

12.2 Type and Grade.

12.3 Compliance with this standard, ASTM DXXXX.

12.4 Other information required by manufacturer or purchaser.

12.5 Marking may be on either seal, packaging, label, or tag.

13. Packaging

13.1 Material shall be protected by suitable packaging to prevent damage during shipment or storage prior to installation in solar collector. 
Table 1. Requirements for Class PS Material

Used to Seal Solar Collectors

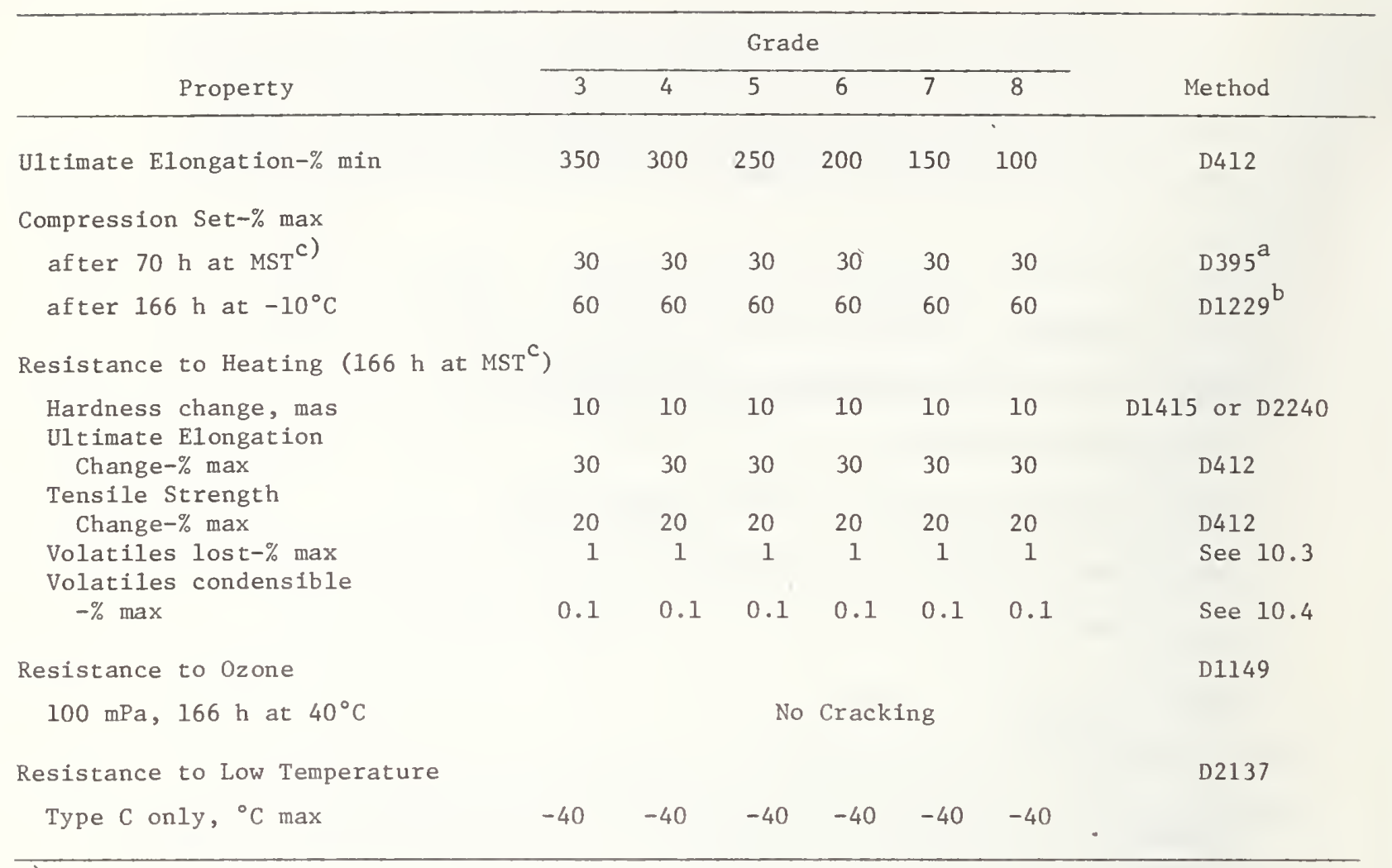

a) Method B

b) Set to be measured at 10 seconds after release. Lubricated plates or polytetrafluoroethylene film is recommended if the rubber adheres to the metal compression plates during test.

c) The test temperature is based on the maximum service temperature (MST) which normally occurs when the collector is under stagnation conditions and receiving the maximum radiation flux. The test temperature listed in ASTM D1349 that is between $25^{\circ} \mathrm{C}$ and $49^{\circ} \mathrm{C}$ above the maximum service temperature is used. These temperatures are: 100, 125, 150, 175, 200, 225 and $250^{\circ} \mathrm{C}$. 
Table 2. Requirements for Class SC Material

Used to Seal Solar Collectors

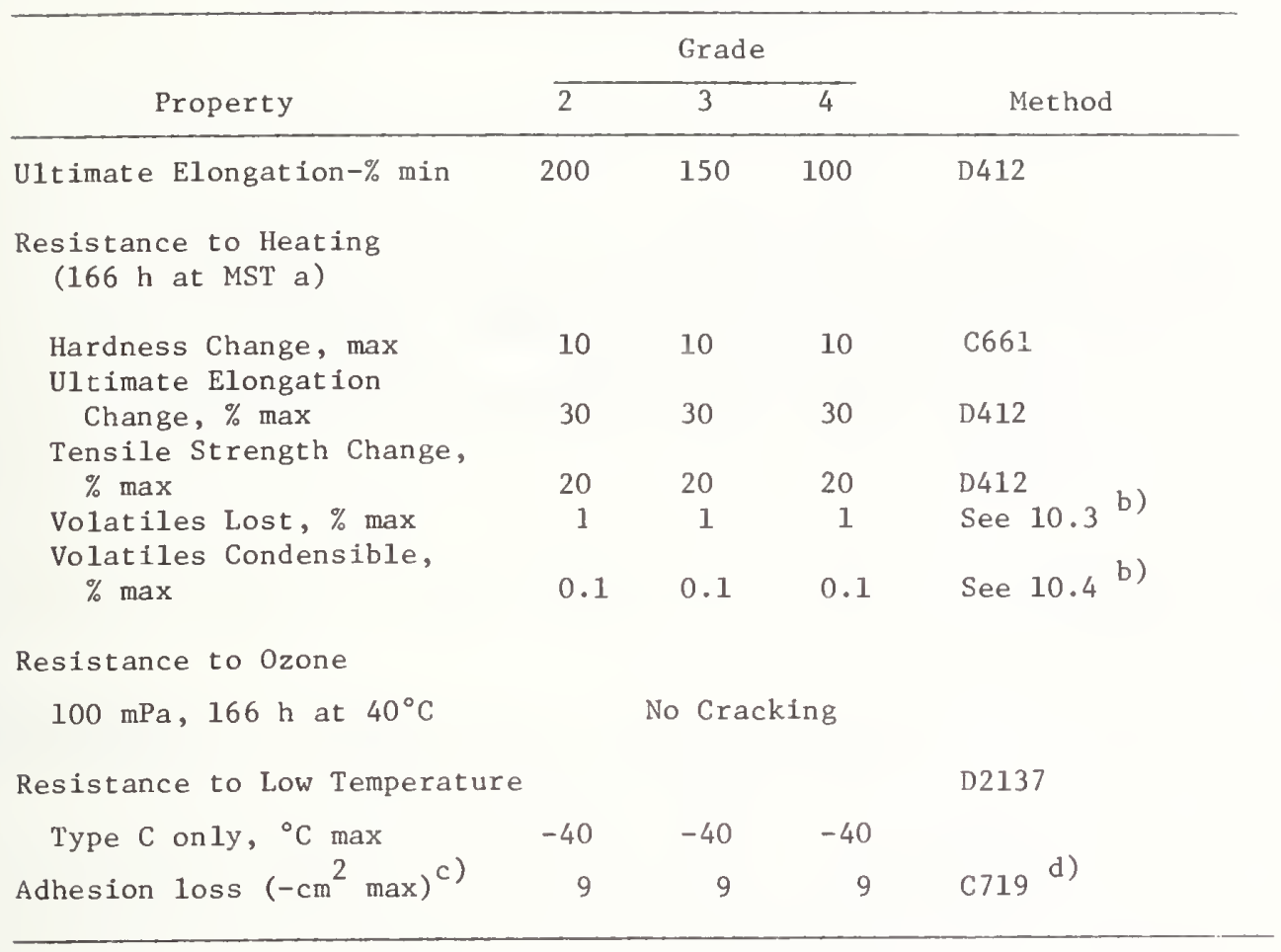

a) The test temperature is based on the maximum service temperature (MST) which normally occurs when the collector is under stagnation conditions and receiving the maximum radiation flux. The test temperature listed in ASTM D1349 that is between $25^{\circ} \mathrm{C}$ and $49^{\circ} \mathrm{C}$ above the maximum service temperature is used. These temperatures are: $100,125,150,175,200,225$ and $250^{\circ} \mathrm{C}$.

b) This test is not required if the design precludes condensing of the volatiles on the cover plate(s) of the solar collector.

c) The combined loss in bond and cohesion areas for the three specimens tested shall not exceed $9 \mathrm{~cm}^{2}$.

d) The temperature in 6.3 of ASTM C719 shall be modified to the MST (see footnote a) above. 
APPENDIX D

PROPOSED STANDARD TEST METHOD FOR DETERMNING

THE EFFECT OF OUTGASSING ON THE TRANSMITTANCE

OF SOLAR COLLECTOR COVERS

1. Scope

1.1 This method covers the determination of the effect of outgassing on the transmittance of cover plates in solar energy collectors. It is applicable to polymeric materials such as rubber seals, insulation and absorptive coatings.

\section{Summary of Method}

2.1 The material to be evaluated is heated in a test apparatus as described in Section 5.1. The condensible decomposition products are collected on a glass plate. The transmittance of the glass plate is measured from 300 to $2100 \mathrm{~nm}$ (in increments of $50 \mathrm{~nm}$ ) before and after testing to determine any change in transmittance resulting from the deposited products. The mass loss of the polymeric test specimen and the weight gain of the glass plate are also determined.

\section{Significance}

3.1 This method can be used to determine the effect of outgassing products on the transmittance of solar collector cover plates and to determine and compare the relative effect of volatile condensible degradation products of specific polymeric materials on cover plate transmittance.

\section{Description of Terms}

4.1 Outgassing - The emission of gases by materials and components, usually during exposure to elevated temperature or reduced pressure. 


\section{Apparatus}

5.1 Outgassing apparatus - a test apparatus containing a controlled temperature heating device, a temperature monitor, an enclosed specimen chamber, a test specimen holder, a glass plate upon which volatiles are condensed and a filtered air stream directed toward the external surface of the glass plate. Figure 1 is a diagram of the individual components of the apparatus and Figure 2 shows the assembled apparatus.

5.2 Spectrophotometer - a spectrophometer as described in ASTM E424-71.

6. Test Specimen

6.1 The test specimen shall consist of a sample of the material. I/

6.2 Specimens of absorptive coatings, which are applied to metallic substrates, shall consist of both the coating and the substrate.

6.3 Specimens of absorptive coatings, which are normally applied to polymers for use in solar collectors, should be applied on a metallic substrate as in 6.2 . 6.4 The size of specimen should be approximately proportional to the ratio of apparatus glass plate area to cover plate areas of solar collector.

7. Conditioning

7.1 Test specimens shall be conditioned at room temperature prior to testing.

8. Procedure

8.1 Measure the transmittance of the glass plate from 300 to $2100 \mathrm{~nm}$ according to ASTM E424-71.

1/ Optimum specimen size as yet to be determined. 
8.2 Weigh the test specimen and the glass plate of the test apparatus to the nearest $0.01 \mathrm{gm}$.

8.3 Adjust the temperature of the test apparatus to the desired test temperature prior to inserting the test specimen and installing the glass plate.

8.4 Place the test specimen in the specimen holder and install the glass plate over the teflon gasket using the spring clips.

8.5 Turn on the air stream and direct the flow to the center of the exterior surface of the glass plate.

8.5 Allow the test to proceed for 3 hours or the time mutually agreed upon by the purchaser and the seller.

8.7 Stop the flow of the air stream, turn off the hot plate and remove the glass plate and the test specimen.

8.8 Allow the test specimen and the glass plate to reach room temperature and weigh both.

8.9 Measure the transmittance of the glass plate from 300 to $2100 \mathrm{~nm}$ according to ASTM E424-71.

8.10 Clean the glass plate with ethyl alcohol for repeat usage. Measure the transmittance of the cleaned plate using the procedure in 8.1 prior to reusing. 
9. Calculations

9.1 Integrate the area under the transmittance curves obtained in 8.1 and 8.9 and calculate the difference between the integrated values.

9.2 Calculate the weight gain of the glass plate and the mass loss of the test specimen.

10. Report

10.1 The report shall include the following:

10.1.1. Identification of the test specimen, including type of material, source or manufacturer, product identification, batch or lot serial number.

10.1.2. Identification of metal used if the test specimen is an absorptive coating applied to a substrate.

10.1.3. Conditioning procedure prior to testing.

10.1.4. Identification of type of glass used as the glass plate, test temperature and test duration.

10.1.5. Test specimen mass before and after test and mass loss.

10.1.6. Glass plate mass before and after test and mass gain.

10.1.7. Integrated transmittance from 300 to $2100 \mathrm{~nm}$ of the glass plate before and after testing and the difference between the two values. 


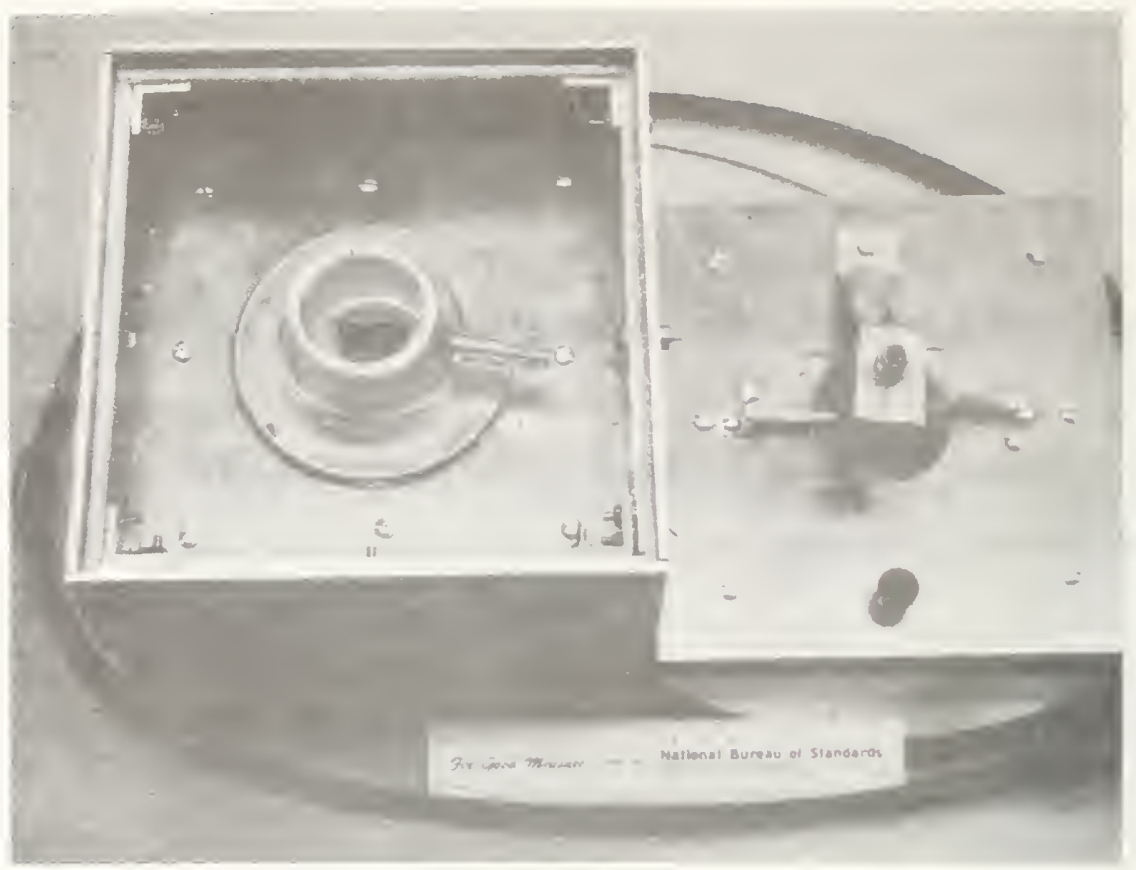

Figure 1. Components of the Outgassing Test Apparatus.

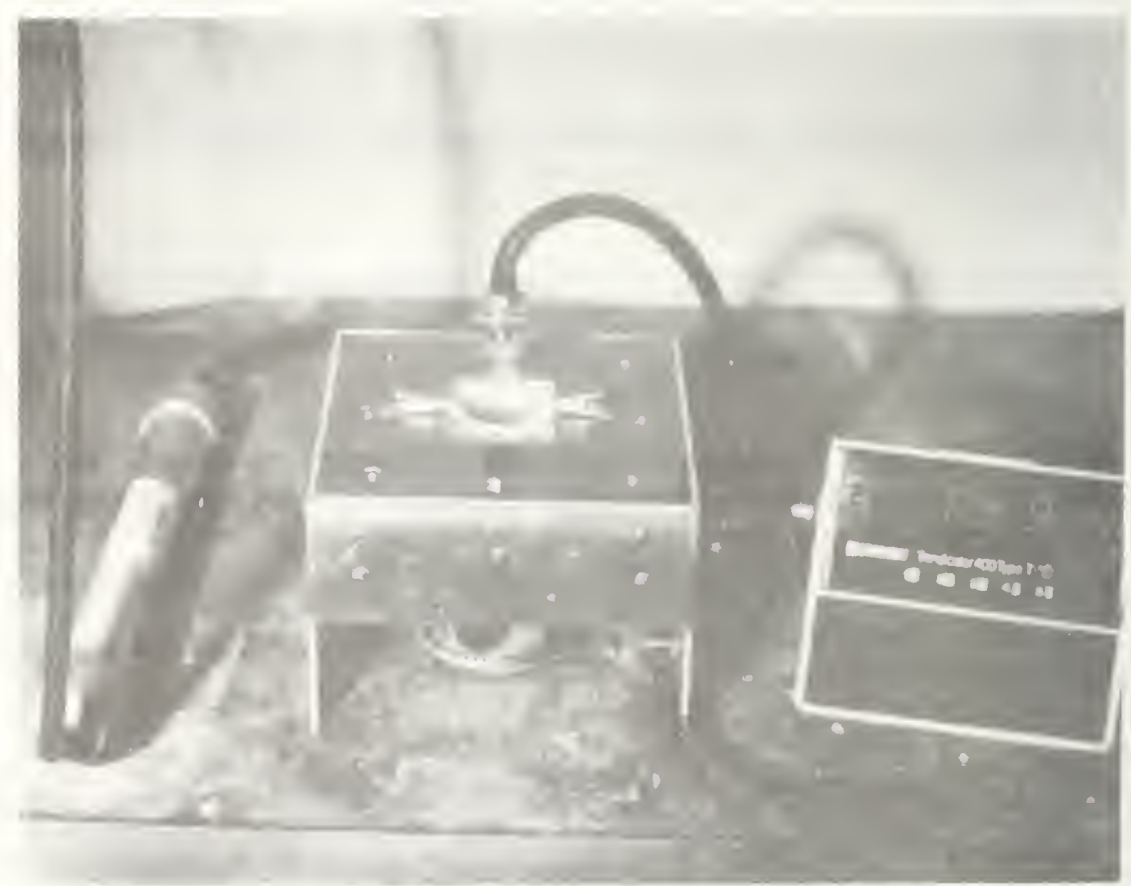

Figure 2. Assembled Outgassing Test Apparatus. 


\section{APPENDIX E \\ RECOMMENDATIONS FOR SEALING JOINTS \\ BETWEEN SOLAR COLLECTORS AND \\ BUILDING COMPONENTS WITH RUBBER SEALS}

\section{Scope}

1.1 These recommendations apply to the sealing of 1) joints between solar collectors integral with building components and those building components and 2) joints between collector standoffs and the roof or other building components.

1.2 These recommendations apply to rubber seals used to seal the joints described in 1.1 .

1.3 The joint sealing compounds covered by specifications listed in 2.0 are intended, among other uses, to seal joints against dust, dirt, wind and water.

2. Compliance with Specifications

Sealants that are selected for use in the installation of solar collectors should meet all the requirements of one of the appropriate following Federal Specifications:

TT-S-00230C (COM-NBS), February 2, 1970, Ammend 2; Sealing Compound: Elastomeric Type, Single Component (For Caulking, Sealing, and Glazing in Buildings and Other Structures). 
TS-S-00227E (COM-NBS), November 4, 1969, Ammend 3; Sealing Compound: Elastomeric Type, Multi-Component (For Caulking, Sealing, and Glazing in Buildings and Other Structures).

TS-S-001543A (COM-NBS), June 9, 1971, Sealing Compound: Silicone Rubber Base (For Caulking, Sealing, and Glazing in Buildings and Other Structures).

\section{Suggested Installation Practices}

3.1 Liquid applied seals are supplied in two types as follows:

(a) one component material in metal, cardboard or plastic cartridges as well as in bulk containers of various capacities; (b) two or more components, usually referred to as base and curing agents or accelerators. Small quantities may be mixed on a board or plate instead of using the base container.

3.2 The compound supplied in cartridges should be installed with either a hand or power gun. Bulk compound should be installed with a caulking gun or with a hand tool.

3.3 It is of prime importance that the joint be dry, free of dust, dirt, oil or grease before the sealant is placed in the joint.

3.4 Sealant producers often recommend the use of a specific primer (or surface conditioner) for specific surfaces. The primer is designed to assure adhesion of the compound to a specific surface. Substituted primers or conditioners other than those recommended by the producer should not be used. 
3.5 Whenever possible, the compound should not be applied to a joint at temperatures below $40^{\circ} \mathrm{F}$. At such temperatures, a film of molsture is likely to form on the surfaces of the joint as a result of condensation that is not readily visible. This invisible moisture film may prevent the formation of a strong bond between the compound and the substrate.

3.6 A sealant should be tooled as soon as possible after application. This is done to force the sealant into the joint and eliminate air pockets. Tooling also insures contact of the sealant to the sides of the joint.

3.7 A sealant should not be placed in a joint if there is evidence that it has begun to cure. 
NBS-114A IREV 7.7\%

\begin{tabular}{|c|c|c|}
\hline $\begin{array}{l}\text { U.S. DEPT. OF COMM. } \\
\text { BIBLIOGRAPHIC DATA } \\
\text { SHEET }\end{array}$ & \begin{tabular}{l|l} 
1. PUBLIC ATION OR RFIPORT NO. & $\begin{array}{l}\text { 2. Gov't Accession } \\
\text { No. }\end{array}$ \\
NBSIR $77-1437$ &
\end{tabular} & 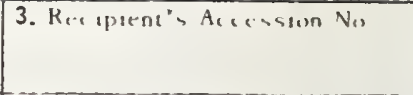 \\
\hline \multirow{2}{*}{\multicolumn{2}{|c|}{$\begin{array}{l}\text { 4. TITLE AND SUBTITI. } \\
\text { SOLAR ENERGY SYSTEMS - STANDARDS FOR RUBBER SEALS }\end{array}$}} & $\begin{array}{l}\text { 5. Publuation Late } \\
\text { March } 1978\end{array}$ \\
\hline & & 6. Pertorming Organization ( ide \\
\hline $\begin{array}{l}\text { 7. AUTHOR(S) } \\
\text { R.D. Stiehler, A }\end{array}$ & Hockman, E. Embree, \& L.W. Masters & 8. Perturming Orgau. Repuri Nu. \\
\hline \multicolumn{2}{|c|}{$\begin{array}{l}\text { 9. PFRFORMING ORGANIZATION NAME AND ADDRESS } \\
\qquad \begin{array}{l}\text { NATIONAL BUREAU OF STANDARDS } \\
\text { DEPARTMENT OF COMMERCE } \\
\text { WASHINGTON, D.C. } 20234\end{array}\end{array}$} & 10. Prolect/lask/Work Inat No. \\
\hline \multirow{2}{*}{\multicolumn{2}{|c|}{$\begin{array}{l}\text { 12. Spunsoring Organization Name and Complete Address (Street, City. State, ZIP) } \\
\text { Division of Solar Energy } \\
\text { Department of Energy } \\
20 \text { Massachusetts Avenue } \\
\text { Washington, D.C. } 20545\end{array}$}} & $\begin{array}{l}\text { 13. Type of Report \& Persod } \\
\text { Covered } \\
\text { Final Report }\end{array}$ \\
\hline & & 14. Sponsoring Agenc y C ude \\
\hline
\end{tabular}

16. ABSTRAC'T' (A 200-word or less tactual summary of most significant information. If document includes a significant biblrography or literature survey, mention it here.)

A study was performed to develop standards for rubber seals used in solar energy systems. Thirty preformed and liquid applied seals were evaluated in the laboratory using modified ASTM standard test methods to obtain data needed to prepare the standards. Also, studies were performed to develop a test method for determining the effects of outgassing on the transmittance of solar collector covers.

The results of the laboratory tests are presented and standards for rubber seals in solar energy systems are proposed.

17. KEY WORI)S (six to twelve entries; alphabetical order; captalize only the first letter of the first key word unless a proper name; separated by semicolons)

Rubber seals; solar collectors; solar energy systems; standards; test methods .

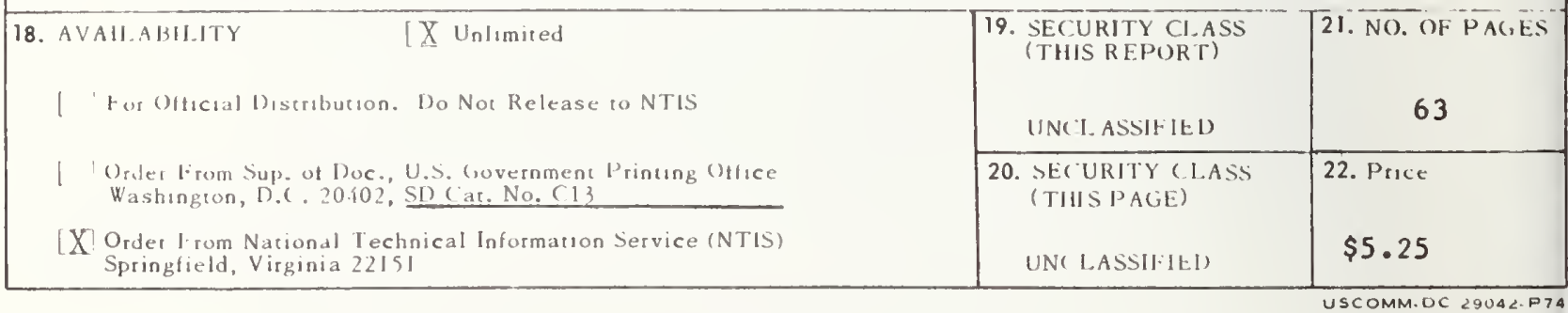

